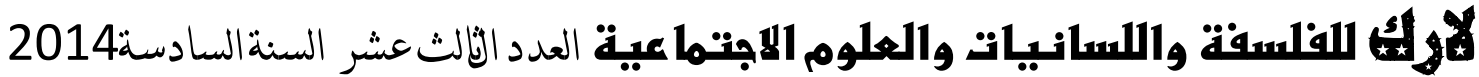

\section{مستوى الرضا النفسي عن العمل الارشادي لاى المرشدين التربويين \\ في محافظة ذي قار}

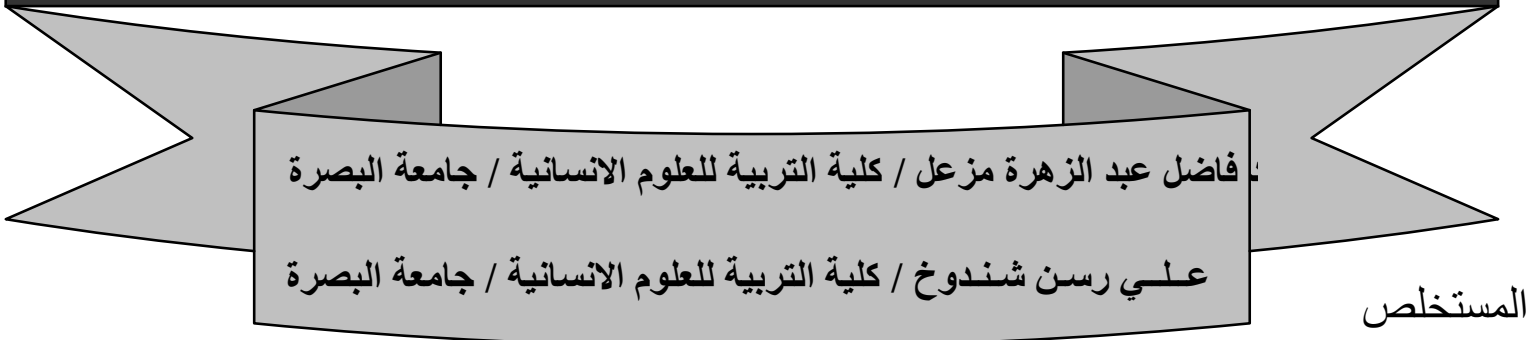

يهذف البحث الحالي الى التعرف على مستوى الرضا عن العمل الارشادي لدى المرشدين التربويين في محافظة ذي قار ، وقد تحدد مجتمع البحث للمرشدين التربويين في المدارس المتوسطة والإعدادية و الثانوية التابعة لمديريات التربية في محافظة ذي قار ، وقد تم اختيار عينة بلغ حجمها ( 250) مرشدا

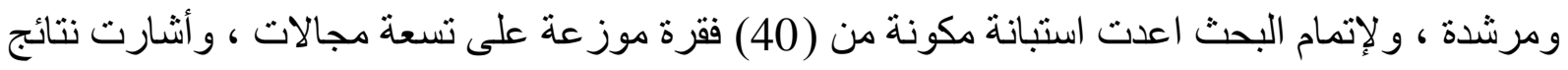

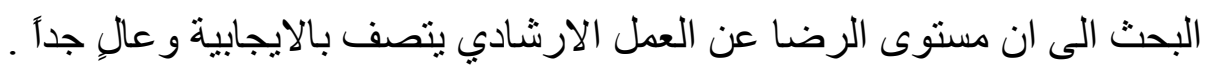

Abstract

Aims Current search to identify the level of satisfaction with the extension work with counselors in Dhi Qar province has been determined by the research community of the guides educators in middle school and junior high and high school belonging to the Education Directorates in Dhi Qar province has been selected sample of them hitting (250) mentor and guide, and complete find prepared a questionnaire consisting of (40) items divided into nine areas, the search results that the level of satisfaction with the extension work is characterized by a very high and positive. 
الفــــل الاو:

مشكلة البحث :

يعد رضا المرشد التربوي النفسي عن العمل قضية مهمة فضلا عن مجتمعه ، ومن العوامل المؤثرة

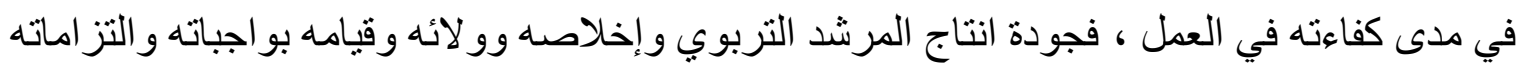

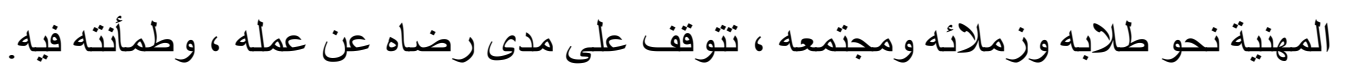

اذ يعد الرضا عن العمل في اي وظيفة او عمل من القضايا الحيوية التي تواجه الاداريين و العاملين

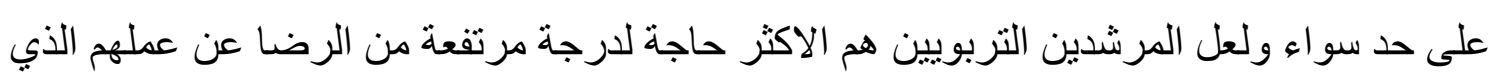

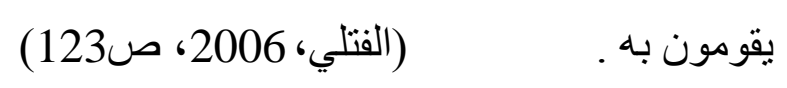

ولضمان فاعلية المرشد التربوي في تحسين مردودية المدرسة من خلال الدور المهم الذي يقوم به ،

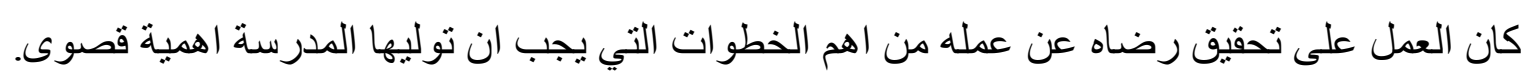
(لباد، 2006، صنان (ل) اهية البحث:

ان دراسة رضا المرشد التربوي عن عمله تكتسب اهية بالغة بالنظر الى الدور الهام الذي يؤديه هذا

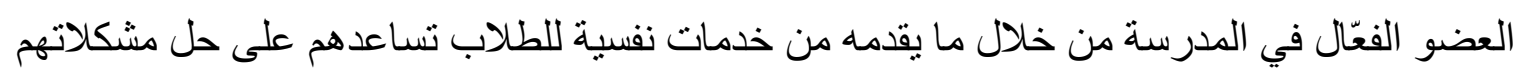

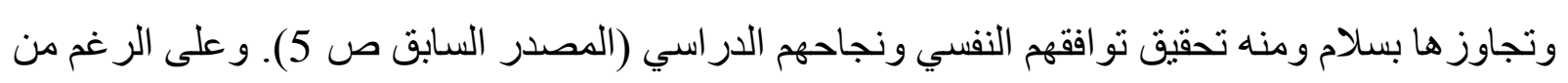

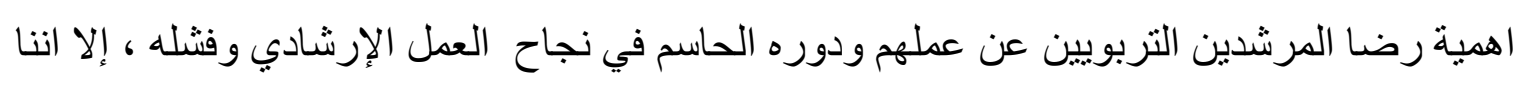
نلاحظ عدم الاهتمام بدر اسة هذا الموضوع در اسة تتناسب مع ما يشكله من اثر في نجاح العملية التربوية

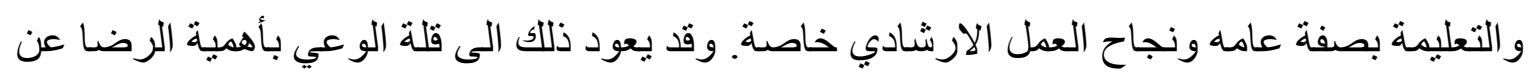

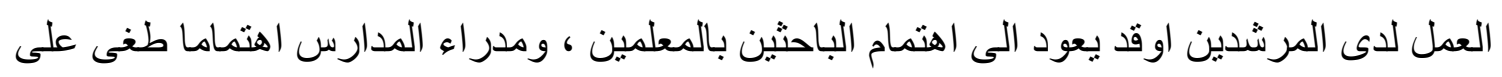

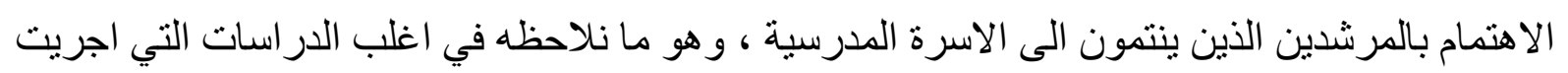

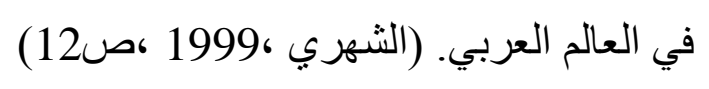




$$
\text { اهداف البحث: }
$$

التعرف على رضا المرشدين التربويين عن عمهم الارشادي بصورة عامة. حدود البحث:

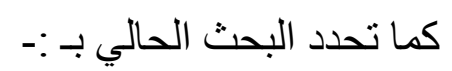
1- المرشدين التربويين من (الذكور والإناث) الذين يزاولون مهنة الارشاد التربوي. 2- المدارس المتوسطة و الإعدادية و الثانوية في محافظة ذي قار. 3- - العام الدراسي ( 2012 - 2013).

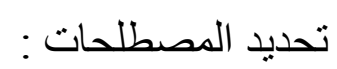

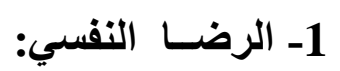
أ-عرفه الثمري ،2007 ،بأنه:-

الحالة التي يشعر بها الفرد بالر احة و الطمأنينة عن ذاته في المحيط الذي يكون فيه ، ويتأثر كل كيانه النفسي بذلك الرضا ، كما ينعكس في مجمل تصر فاته ونشاطه وحركته في ذلك المحيط. (الثهري ،2007) (238) (20) ب-عرفه يوسف ،2008 ،بأنه :بأنه حالة شعورية تعكس رؤية الفرد و إدر اكه وحبه وسعادنه بشأن ما في بيئته) (يو سف 
انه النمط او سلوك القائد في رسم وتخطيط العلاقة بينه وبين اعضاء مجمو عة العمل ومحاولة تثبيت انماط محددة واضحة بشكل جيد و إيجاد قنو ات رسمية للاتصلال ، وطرق الاجر اءات فيها بينه وبين (Halpin, 1966, p.86) مرؤوسيه.

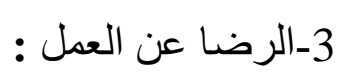
أ- عرفه سلامة ،2003 ،بأنه :- (203 هو محصلة عناصر الرضا التي يتصور الفرد انه يحصل عليها من عمله وهي الرضا عن أجره

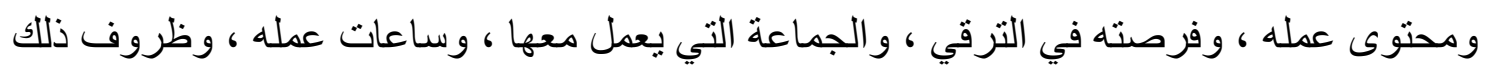

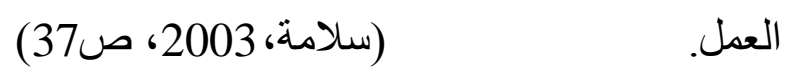
ب-عرفه كابلن(kaplan,1982) (-)

بأنه حصيلة مجمو عة من العو امل المختلفة المتصلة بالعمل التي من شانها ان تجعل الفرد راضيا

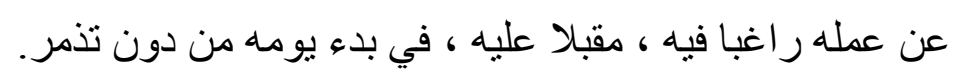

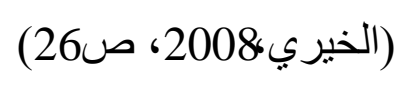$$
\text { ج- عرفه الروقي ،2012 ، بأنه :- }
$$

بأنه "شعور داخلي يكون ايجابيا نحو العمل فيزيد من الإنتاج او سلبيا فيؤدي الى التقاعس عن

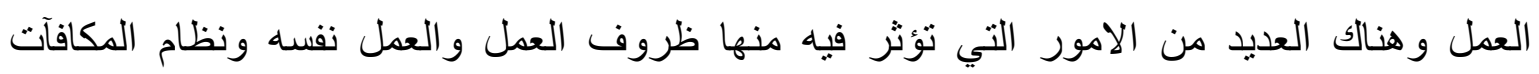

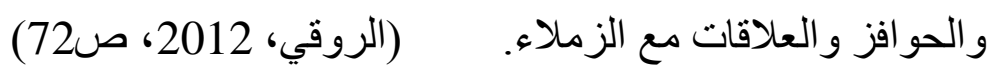

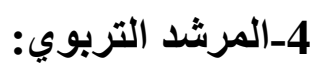

$$
\begin{aligned}
& \text { أ_عرفه كود (cood,1973) :- }
\end{aligned}
$$


هو الشخص الذي يساعد الطلاب ويعمل على التكيف و الاختبار بما يتعلق بأمور هم الخاصة على ه. وفق مشكلات كل فرد منهم سو اء كانت تربوية او مهنية او شخصية وهو مختص بالنصح الفردي

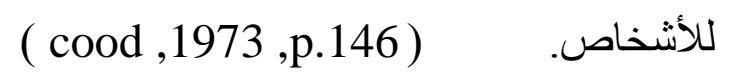$$
\text { ب-عرفته وزارة التربية :- }
$$

هو احد اعضاء الهيئة التدريسية المؤهل لدر اسة مشكلات الطلاب التربوية والصحية والاجتماعية

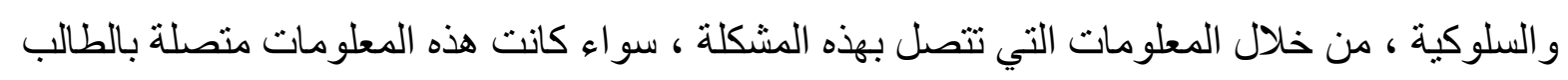
نفسه ، ام بالبيئة الحيطة به ، لغرض تبصيره بمشكلته ، ومساعدته على ان يفكر بالحلول المناسبة لهذه المشكلة او المشكلات التي يعاني منها لاختيار الحل المناسب الذي يرتضيه لنفسه. (العلياوي، 2012، ص212) 
الفصل الثاني

الاطار النظري ودراسات سابقة

لمحة تاريخية حول الرضا عن العمل:

تعود بدايات الاهتمام بموضوع الرضا عن العمل وتأثثيره في سلوك الافر اد الى بدايات القرن

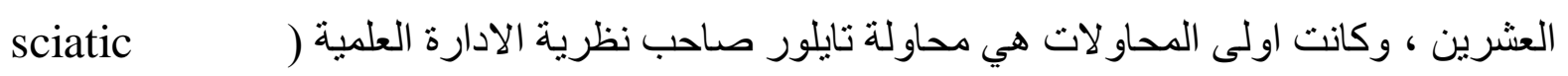
(management theory في المنظمة ، وفي كيفية تحفيزه من اجل المزيد من العطاء والبذل ، إذ قام فريدريك تايلور ( 18561917) بوضع نظرية الادارة العلمية في بدايات القرن العشرين كطريقة لجعل ادارة انشطة العمل أكثر كفاءة ، و الافتر اض الرئيس للدو افع حسب هذه النظرية هو أنَّ الافر اد العاملين مستعدون للعمل بجد من اجل الحصول على المكافآت المالية ، فالعاملون يعطون الحوافز المادية اهمية كبرى ، ولكن لم تستطيع هذه الادارة تحقيق الرضا المطلوب للعمال وكان يؤخذ عليها اهمالها للجوانب الانسانية في حياة العمال إلا أنها لفتت الانتباه للعنصر البشري في العمل و الى قدر اتهم وتأهيلهم وتحفيز هم للعمل.

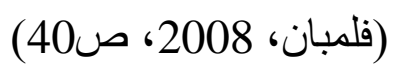

وفي المدة نفسها ظهرت حركة اخرى في الفكر الاداري والصناعي ، وهي حركة العلاقات الانسانية إذ قام مصنع هوثورن ( 1924-1934) في ضو احي مدينة شيكاغو في الولايات المتحدة الامريكية بسلسلة تجارب اظهرت النتائج وجود متغير هو معنوية العاملين بوصفه المتغير الاساس الذي يؤثر في كفاية الانتاج وأثبتت التجارب ان معنويات العاملين تتأثر اكثر مما تتأثر بعلاقات العمل التي تمثل الجانب الانساني للإنتاج. و عند ذلك اخذت الادارة علاقات العمل اساسا لسياسة جديدة في العلاقات الانسانية وركيزة لنظام الاشر اف السائد ومنهجا لتدريب المشرفين على معاملة العاملين ، ويعد التون مايو ( Elton Mayo) وزملاؤه ممن تلتصق بهم حركة العلاقات الانسانية من الرواد الاوائل الذين اعطو ادفعة علمية لهذه الحركة فقد تضمنت هذه الحركة عدة افكار أهمها المكافآت والحو افز غير المادية وتلعب دور ها الرئيس في تحفيز الافر اد وشعور هم بالرضا ـ و وان حجم العمل الذي يؤديه الفرد ومستوى 
كفاية الانتاج لا يتحدد بطاقته الفسيولوجية فحسب و إنما تحدده ار ادة الجماعة وخلفيته الانسانية ـو وقد شخصت هذه المدرسة معنويات العاملين وعلاقات العمل من اثر انتاجهم. (الزبيدي، 2010، ص39) وفي عام (1935) قام هوبوك ( Hoppock) بدر اسة الرضا عن العمل لدى عمال مصنع صغير بقرية (New Hope) بو لاية بنسلفانيا بالو لايات المتحدة ، إذ سأل الباحث في هذه الدر اسة سؤ الين: الاول : الى اي مدى يكون الافر اد في مهنة معينة اكثر سرورا من غير هم في مهن اخرى؟ الثاني : الى اي مدى يكون العمال في (New Hope) مسرورين بصفة مطلقة؟ وتعد هذه الدر اسة اول در اسة تركز على الرضا عن العمل ، ونقطة الانطلاق لجميع الدراسات المتعلقة بالرضا عن العمل او الرضا الوظيفي الحالية.

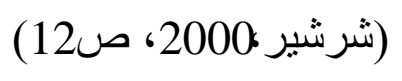

اذ درس العوامل التي تؤثر في الرضا في العمل مثل التعب وظروف العمل و الإشر اف وقد كانت هذه الدر اسة هي النواة لجميع الدراسات الحالية التي كانت وما تز ال تسعى الى تغيير البيئة ، وتحسين

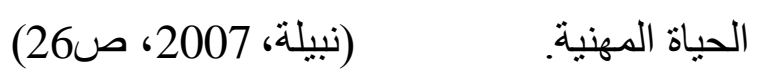

وفي عام (Herzberg) نقدا مشهور اللإنتاج الفكري في مجال الرضا عن العمل ، إذ انتقد نظرة هوبوك (Hoppock) التقليدية التي تتص على ان الرضا عن العمل متغير مستمر Dichotomous و اقتر ح بدلا من ذلك ان يكون الرضا متغير ا ثابتا (Continuos Variable) (Variable ) ، كما اقترح ايضا النظر الى العو امل المؤدية الى الرضا عن العمل على انها متميزة عن العو امل المؤدية الى عدم الرضا عن العمل. وفي الستينات من القرن الماضي اصبحت ابحاث الرضا عن العمل اكثر نضوجا، وتم تطوير المناهج المسحية ، وكثر استعمالها في جميع المعلومات التي تجيب عن تساؤلات الباحثين. (الويس، 2011، صو74) (2011) 
في السبعينات اصبحت ابحاث الرضا الوظيفي حقلا مستقلا بذاته إذ وضعت في هذه المدة معظم

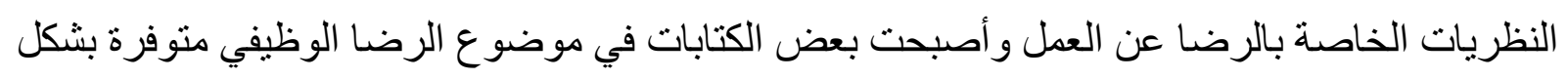
(نسيم، اكبر و اتسع مجال التطبيق ليشمل العديد من الوظائف الجديدة. (94) 2012

$$
\begin{aligned}
& \text { بعض النظريات التي فسرت الرضا عن العمل : } \\
& \text { او لا - نظرية الحاجات(ابر اهام ماسلو) : }
\end{aligned}
$$

تعد نظرية سلم الحاجات التي وضعها ابر اهام ماسلو من اكثر النظريات شيو عاوقدرة على تفسير سلوك الانسان وتقوم نظرينه على مبدأين اساسيين:

أـ ان حاجات الفرد مرتبة تصاعديا على شكل سلم او هرم حسب اولويتها للفرد (و هذا لا يعني التتابعية بل هناك امكانية للققز عن بعض الحاجات بحسب التتشئة و الدين و الثقافة و المبادئ التي يؤمن بها الفرد. بـ ان الحاجات غير المشبعة هي التي تؤثر في سلوك الفرد وتدفعه للعمل اما الحاجات المشبعة فلا تؤثر

$$
\begin{aligned}
& \text { (حمادات، 2008، ص134) } \\
& \text { في سلوك الفرد. }
\end{aligned}
$$

1 physiolcgical Needs الحاجات الفسيولوجية

و هذه تمثل الحاجات الاساسية اللازمة لبقاء الانسان واستمر اريته على قيد الحياة كالطعام و الماء و الهو اء و الجنس ، و الحاجات الفسيولوجية تسيطر على بقية الحاجات اذا لم تكن مثبعة. 2- safcty \& security حاجات الامن والسلامة

تتضمن هذه حاجات الفرد للحماية من الاخطار الجسمية والصحية والبدنية ، وكذلك الحماية من

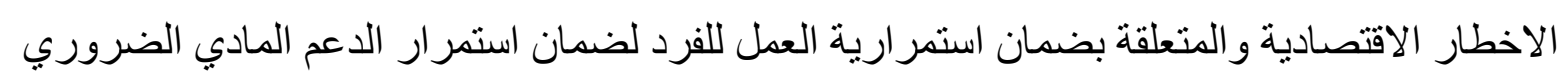
للمحافظة على مستوى معين من الحياة المعيشية. 3- social needs (الحاجات الاجتماعية (الحاجة الى الانتماء) 
تنبع هذه الحاجات من كون الانسان اجتماعيا بطبيعته ويعيش ضمن جماعة ويتفاعل معها. وتشمل

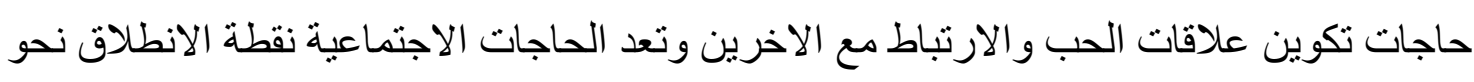

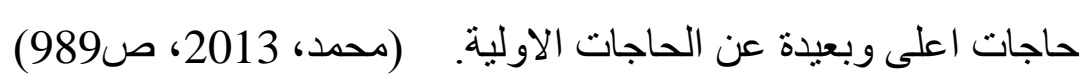

4- fsleem and filfrespect حاجات التقدير والاحترام وتمثل موقفا اعلى في سلم ترتيب الحاجات ويمكن ادر اكها من جانبين :-

أ- جانب داخلي يتعلق بالمكانة الذاتية ، و الحاجات المتعلقة بالثقة بالنفس والاستقلال ، و القدرة على الإلى

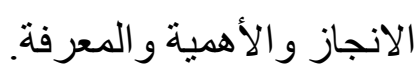

بـ- جانب خارجي يتعلق بالسمعة والحاجة لكي يكون للفرد وضع اجتماعي مقبو لا ، و التقدير من طرف الاخرين.

\section{5- self - Actualzation حاجات تحقيق الذات}

وتمثل قمة الحاجات في هرم "ماسلو" و هي تتعلق بالحاجات الخاصة بنجاح الفرد في التعبير عن

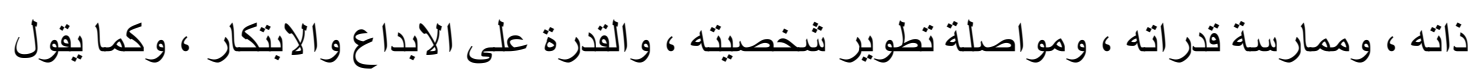

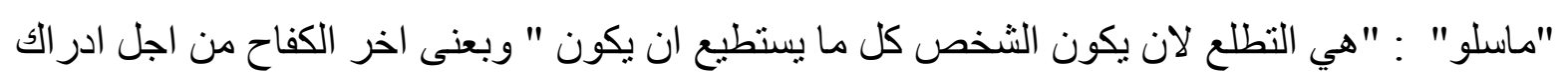

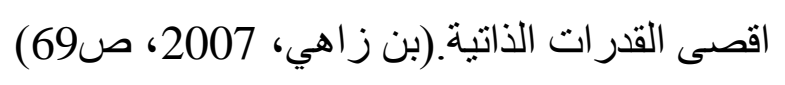

واعتبر ماسلو الحاجات الثلاث الاولى ، حاجات المستوى الادنى ، اما الحاجات الرابعة والخامسة

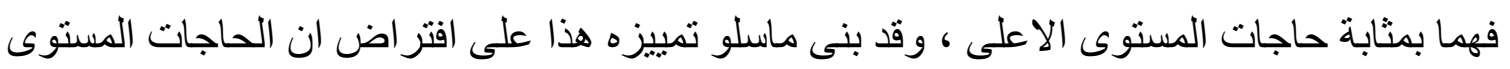

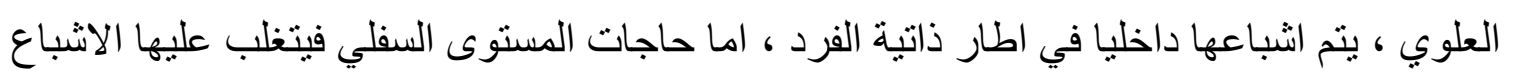

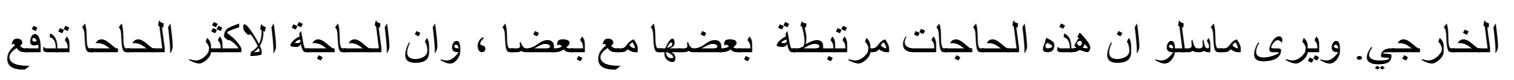

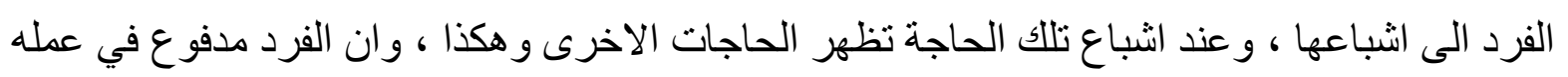
لكي ينجزه ويؤديه ، لان ذلك يؤدي الى انشباع حاجاته الداخلية. و النقطة الجوهرية في هذه النظرية هي ولني

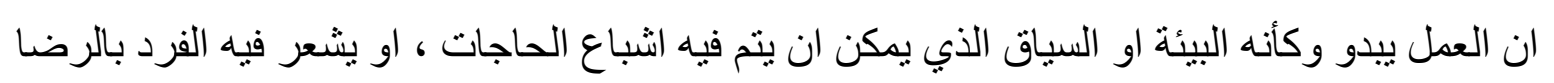

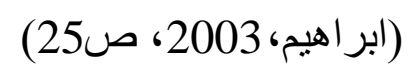
نتيجة لذلك.
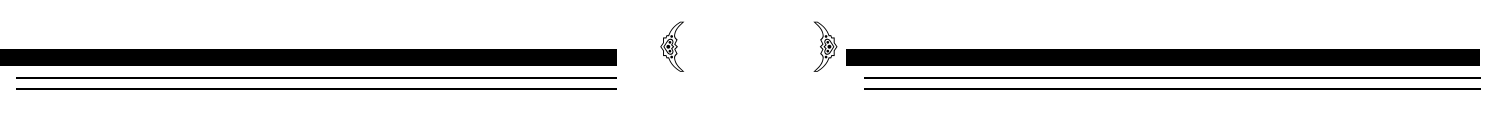
ثانيا ـ نظرية ذات العاملين Two-Factor Theory

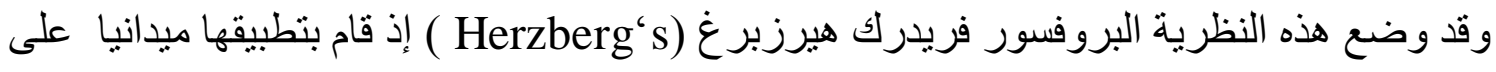

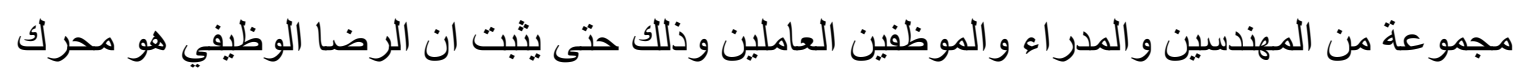

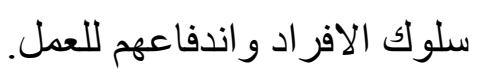

وقد اشارت هذه النظرية الى ان عوامل تحقق الرضا الوظيفي مرتبطة بالنمو النفسي وتحقيق الذات في حين ترتبط العو امل التي تؤدي الى عدم الرضا الوظيفي بالمظاهر البيئية الخارجية للوظيفة.

وان هذه النظرية حاولت تحديد العو امل الرئيسة المسبية للرضا الوظيفي من عدمه ، إذ نوصلت الى الى

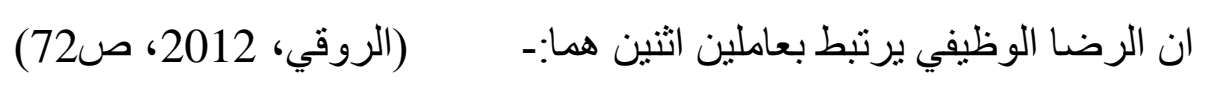
1- عوامل وقائية / ويؤدي عدم وجود او توافر هذه العو امل في بيئة العمل الى حالة الاستياء و عدم

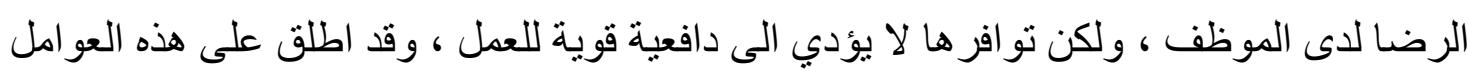

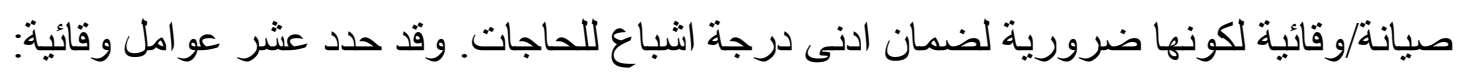
1- العلاقات مع المرؤوسين 6- سياسة المؤسسة وادارتها

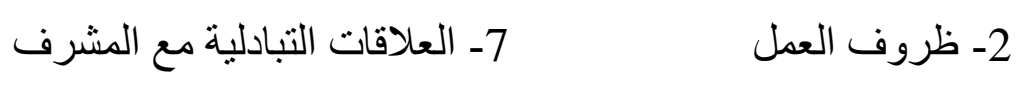

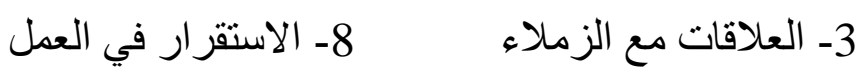

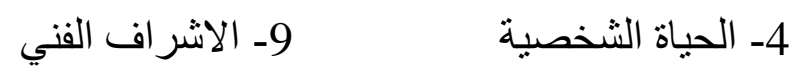
5- الر اتب

2- عوامل دافعية / هناك بعض العوامل المرتبطة بجوهر العمل ، وأطلق عليه العوامل الدافعية ، اذا

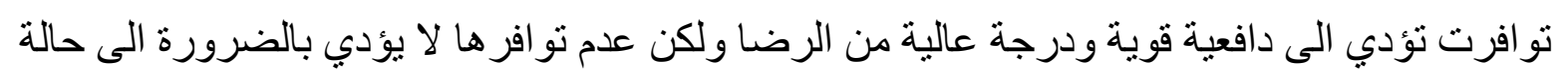

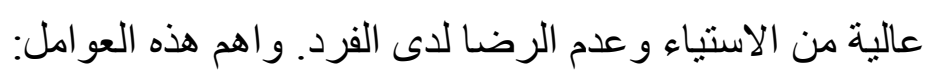

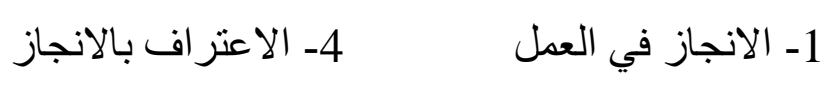


2- التقام و التزقي في العمل 5- طبيعة العمل نفسه ومستواه 3- امكانية النمو و التطور الثخصي

وقد استنتج هيرزبيرغ ان العو امل المُرضية في العمل كانت تتعلق بمضمون العمل و العو امل غير

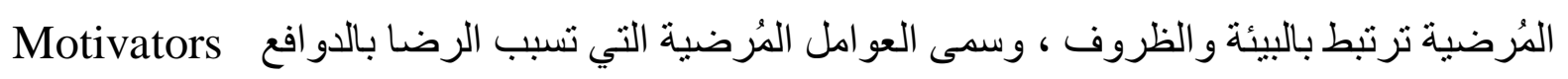

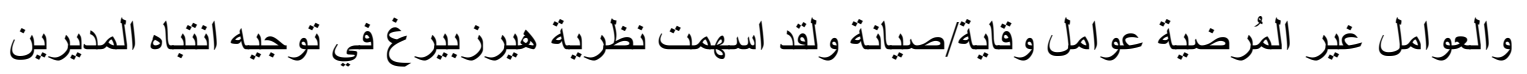
الى عو امل اخرى غير المرتب ، وظروف العمل و السياسات......التي يمكن ان تدفع العاملين للعمل.

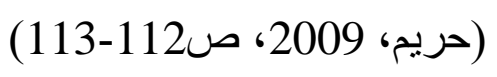

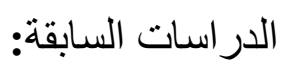
- دراسة علاونة وندى (2005) : بعنوان (مستوى الرضا الوظيفي لاى المرشدين التربويين في محافظتي جنين وقلقبلية) هدفت هذه الدراسة الى التعرف على مستوى الرضا الوظيفي لاى المرشدين التربويين في محافظتي

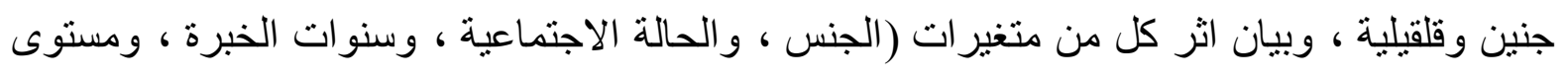

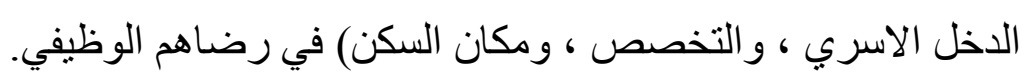
وتكون مجتمع الدراسة من (83) مرشدا تربويا في محافظتي جنين وقلقيلية في الفصل الدراسي

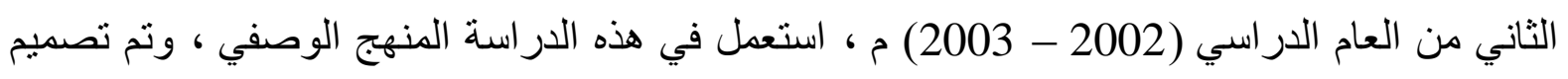

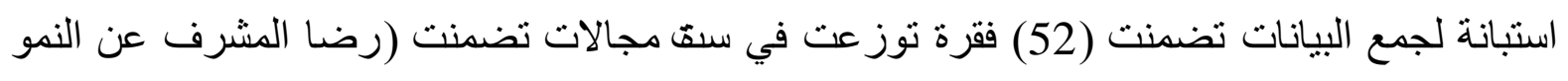

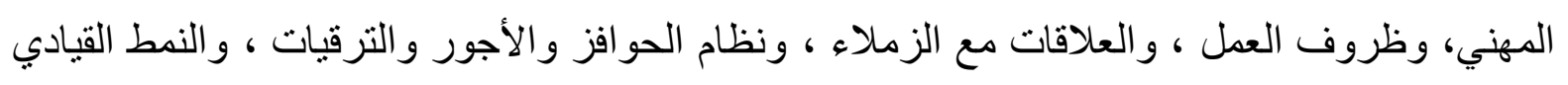

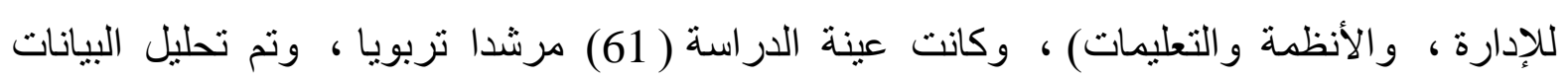
باستعمال المتوسطات الحسابية الموزونة والانحرافات المعيارية ، و وتحليل التباين متعدد القياسات المتكررة ، واختبار سيدالك واختبار (t) وتحليل التباين الاحادي. وقد توصلت الدر اسة الى نتائج ابرزها : 
1- ان مستوى الرضا الوظيفي لدى المرشدين التربويين في محافظتي جنين وقلقيلية اعلى من المتوسط العام إذ بلغ المتوسط الحسابي (3,37).

2- توجد فروق ذات دلالة احصائية في مستوى الرضا الوظيفي لدى المرشدين التربويين تعزى لمجالات الدراسة.

3- لا توجد فروق ذات دلالة احصائية في مستوى الرضا الوظيفي لاى المرشدين التربويين تعزى

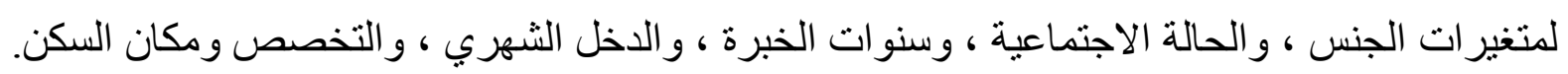

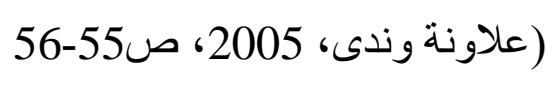

دراسة بيج (page 1980)

$$
\text { بعنوان (العلاقة بين عمر المرشد والرضا وعدم الرضا في العمل) }
$$

اجريت هذه الدراسة (في لورفيلد) بهدف التعرف على العوامل التي تساعد الرضا وعدم الرضا في

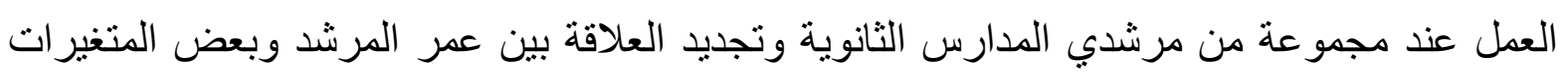
(الحالة الثقافية ، الخبرة ، الرضا عن العمل) وقد استخدمت الدراسة اسلوب المقابلات الثخصية المسجلة

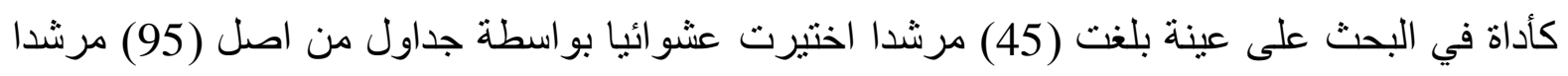

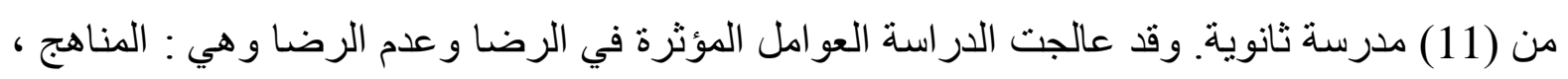
سياسة الحكومة ، فهم دور المرشد التربوي ، تثمين الانجاز في العمل ، الخبرة ، عمر المرشد. ） (page ,1980,p.51)

: (Curtis et ai,1999)

بعنوان ( الرضا الوظيفي لدى المرشدين النفسيين في ضوء المتغيرات بعض المتغيرات الديمغر افية)

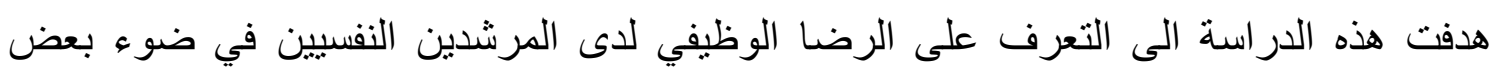

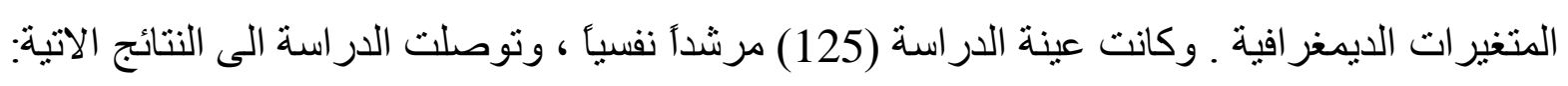


1- وجود رضا وظيفي عالٍ لدى افر اد العينة بالنسبة لطبيعة العمل و العلاقة والاشر اف.

2- وجود رضا وظيفي منخفض لدى افراد العينة بالنسبة الى (الراتب ، فرص ، الترقية).

3- ان المرشدين الذين يتقاضون راتبا اعلى لديهم رضا وظيفي اكثر من المرشدين الذين يتقاضون راتب

(Curtis et ai , 1999)

اقل.

دراسة ديماتو (DeMato,2002)

بعنوان (مستوى الرضا الوظيفي للمرشدين في مدارس ولاية فرجينيا) هدفت هذه الدراسة الى في

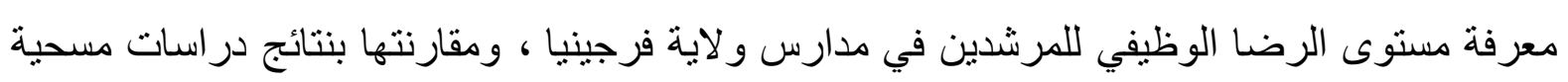
اجريت عام (1988) عن عامي (1985) و (1988) للمرشدين في نفس الددارس.

استعمل في الدراسة المنهج الوصفي، فاستعملت استبانتان عبارة عن مقياسين هما مقياس (IIF) ومقياس مينيسوتا للرضا الوظيفي،ارسلت بالبريد الى (444) مرشدا في مدارس فرجينيا الابتدائية ،

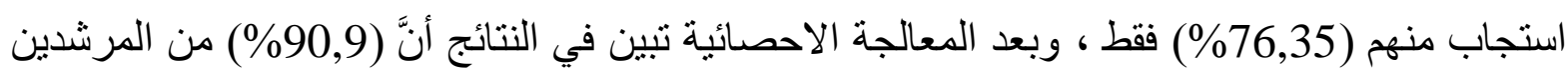

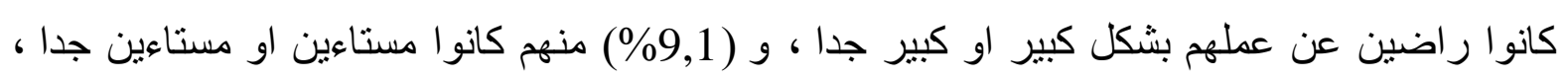

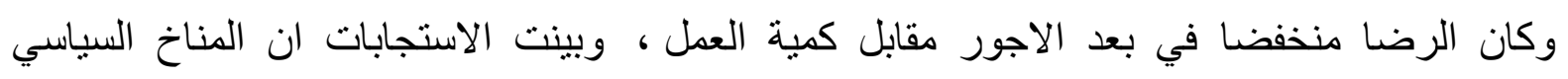

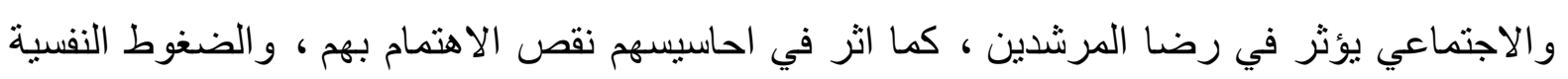

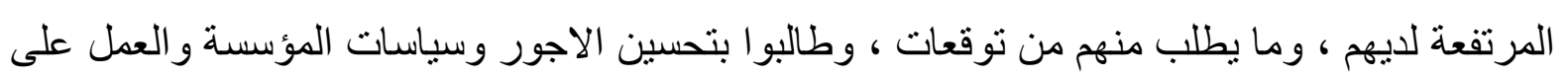
التنمية. ونتيجة المقارنة بالدر اسات المماثلة عام (1988) تبين أنَّ درجة الرضا منماتلة مع نقصان بسيط في

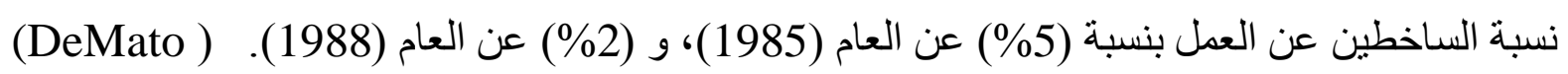




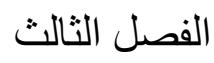

الطريقة والاجر اءات

منهج البحث:

يعد البحث الحالي من الدر اسات الوصفية الارتباطية ، وذللك لكونه يتناول العلاقة بين متغيرين

هما (الرضا عن العمل وبعض سمات الثخصية) لدى المرشدين التربوبين.

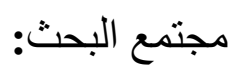

يتكون مجتمع البحث الحالي من جميع مرشدي ومرشدات المدارس المتوسطة والإعدادية

و الثانوية في مديريات التربية في محافظة ذي قار للعام الدراسي ( 2012- 2013) و البالغ عددهم

(308) مرشدا ومرشدة موز عين على اربع مديريات للتربية ، كما موضح في جدول (1):

(1) جدول

أفراد مجتمع البحث في محافظة ذي قار موزعين حسب المديريات للعام الدراسي

(2013-2012)

\begin{tabular}{|c|c|c|}
\hline عدد المرشدين & المـــيـريــات & ث \\
\hline 98 & 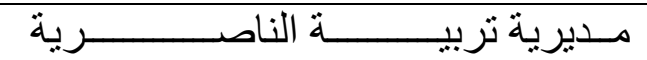 & 1 \\
\hline 38 & مــديرية تربيــــــــة سوق الثيوخ & 2 \\
\hline 79 & 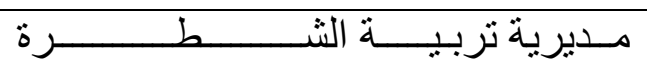 & 3 \\
\hline 93 & 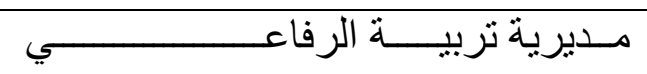 & 4 \\
\hline 308 & المــجـــوع & \\
\hline
\end{tabular}


لكي تكون عينة البحث الحالي ممثلة مجتمعها الاصلي و الخاضعة للار اسة،ققد اختيرت عينة

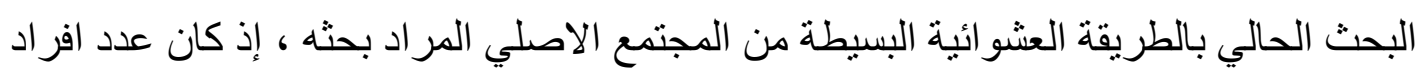

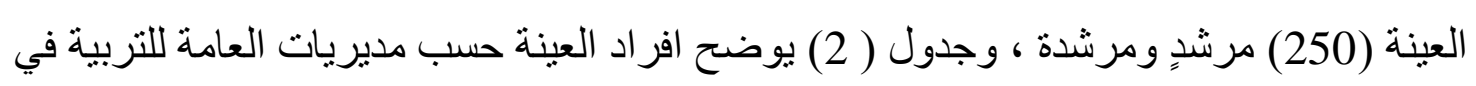
محافظة ذي قار.

\section{جدول (2)}

عدد افراد العينة حسب مديريات العامة للتربية في محافظة ذي قار للعام الدراسي (2013-2012)

\begin{tabular}{|c|c|c|}
\hline عــد المرشدين & 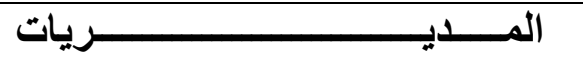 & ت \\
\hline 78 & مـديـرية تربيـة الناصـرية & 1 \\
\hline 31 & مديرية تربية سوق الثشيو خ & 2 \\
\hline 65 & مـــيــرية تربيـــة الثطــــــرة & 3 \\
\hline 76 & مــديرية تربيــة الــرفاعي & 4 \\
\hline 250 & المـــجــــــــــوع & \\
\hline
\end{tabular}

إعداد : الباحث

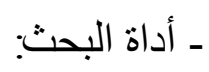
مقياس الرضا عن العمل الإرشادي بعد استعراض الإطار النظري والمقاييس السابقة في مجال الرضا الوظيفي والرضا لرضا عن

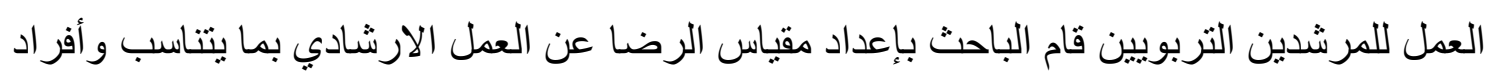

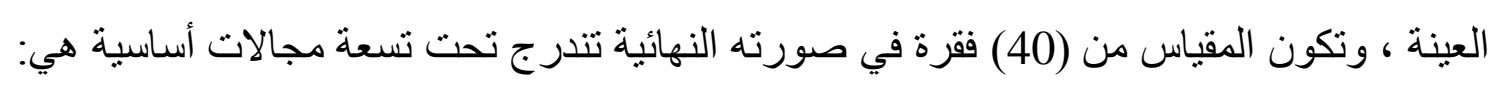




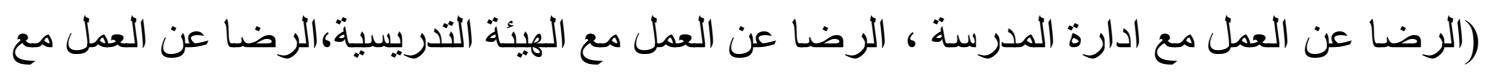

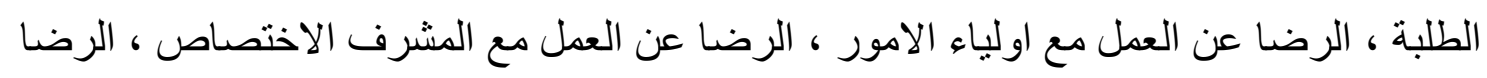

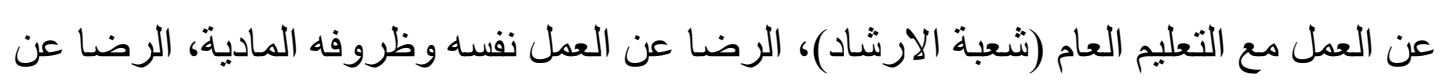

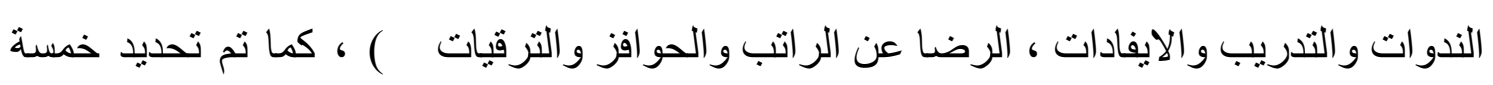

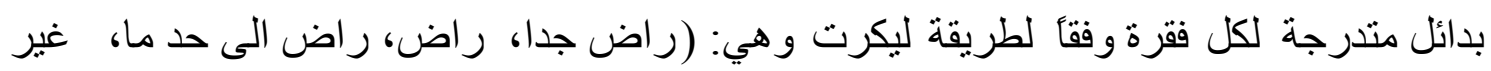

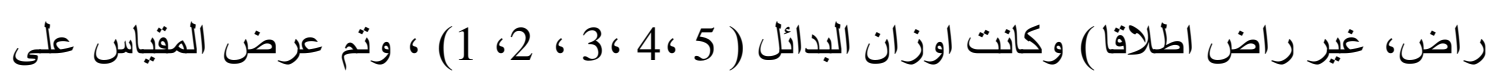

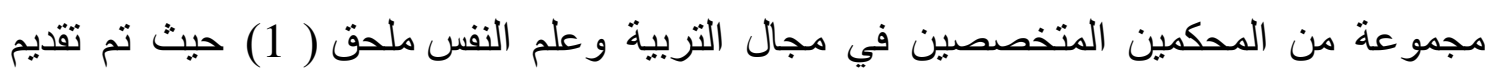
المعلومات اللازمة للتحكيم وطلب منهم قراءة المفردات التي تضمنها المقياس ، وقد قام الباحث

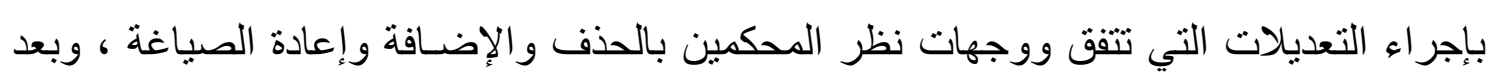

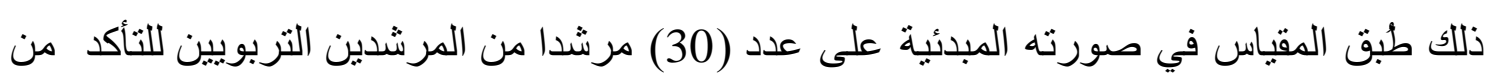

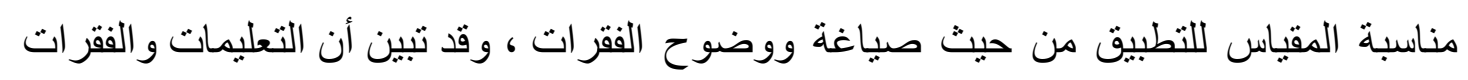

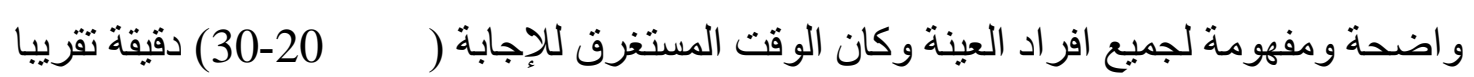
وبمتوسط (25) دقيقة الصدق :

يعد الصدق من الخصائص المهمة التي يجب الاهتمام بها في بناء الاختبار ات. (الجلبي،

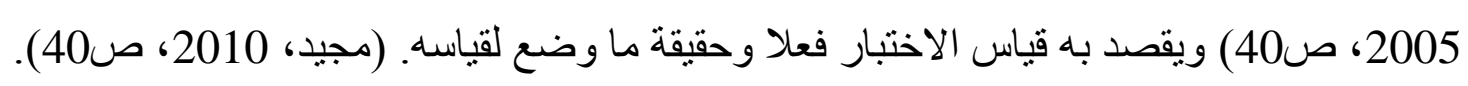

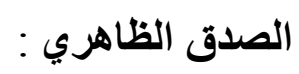

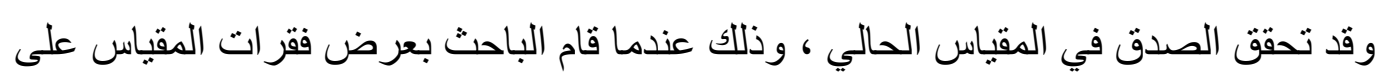

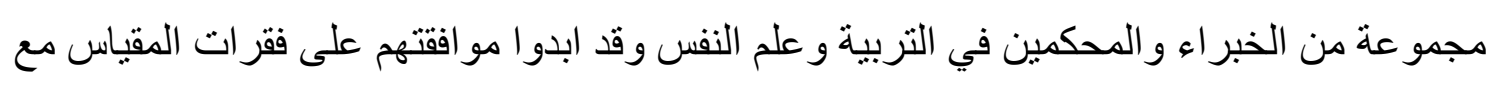

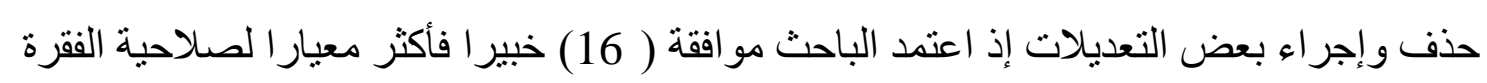

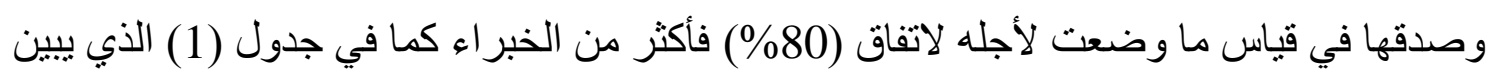

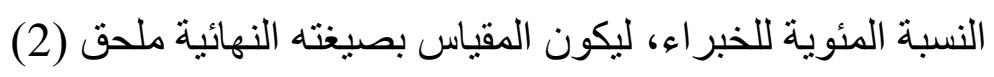


جدول (1) (1) (1)

يوضح نسب اتفاق الخبراء و المحكمين على فقرات المقياس

\begin{tabular}{|c|c|c|c|c|c|}
\hline المئوية & عداجة الى عدو افقين & عدالد غير & صدد المو افقين & الخبر اء & ارقام الفقرات \\
\hline$\% 100$ & - & - & 10 & 10 & 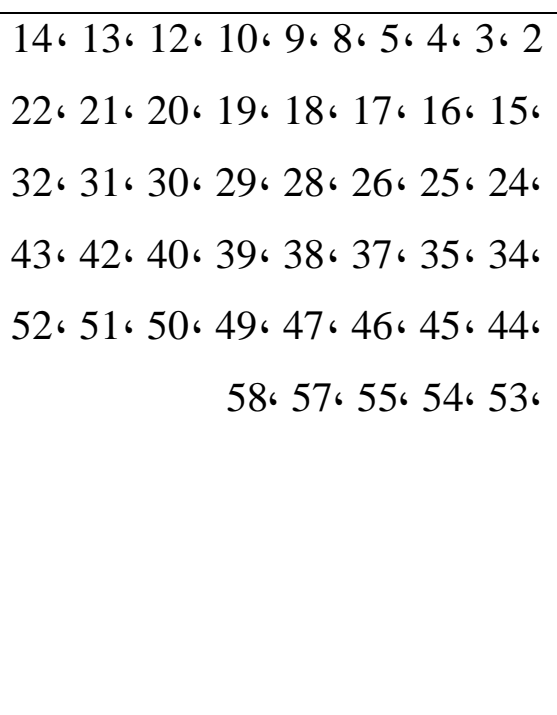 \\
\hline$\% 80$ & 8 & - & 2 & 10 & (1) 4 \\
\hline$\% 60$ & - & 6 & 4 & 10 & 6، 11، 27، 33، 36، 41، 56، 59 \\
\hline
\end{tabular}


استخدم الباحث طريقة إعادة ألاختبار فقد قام الباحث بتطبيق الاختبار على أفر اد العينة الاستطلاعية مرتين بحد فاصل (14) يومأ ، وكان معامل الثبات ( 0.86) وهو معامل ثبات مقبول .(Nunnally ,1978, P.235) الوسائل الاحصائية :

استعان الباحث بالحقيبة الاحصائية ( spss) لتحليل البيانات سو اء في بناء المقياس ام بتحليل البيانات النهائية ولمعالجة نتائج البحث احصائيًا ، وقد استعملت الوسائل الاحصائية الاتية: 1- معامل ارتباط بيرسون : استعمل في حساب الثبات 2- الاختبار التائي لعينة واحدة : استعمل في حساب الوسط الحسابي والانحر اف المعياري و الوسط الفرضي لعينة البحث. 3- النسبة المئوية : لإيجاد نسب اتفاق الخبراء على فقرات الاداة ـ (الجادري، 2003، ص96) 


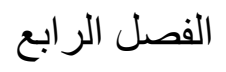

$$
\begin{aligned}
& \text { عرض النتائج وتفسير ها } \\
& \text { بعد تحليل البيانات ومعالجتها احصائيا توصل البحث الى النتائج الاتية :- } \\
& \text { تضمن هدف البحث : } \\
& \text { التعرف على رضا المرشدين التربويين عن عملهم الارشادي . }
\end{aligned}
$$

اظهرت النتائج بأنَّ الوسط الحسابي لإفراد عينة الدراسة على مقياس الرضا عن العمل الارشادي

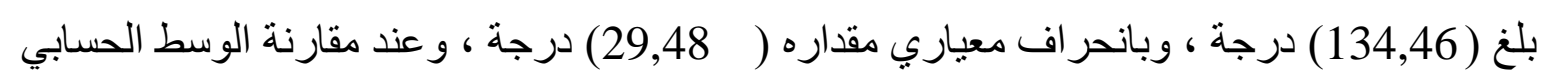

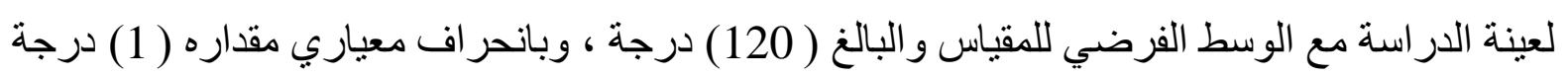

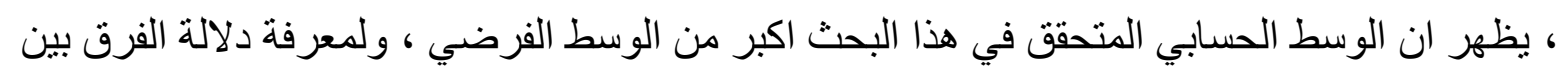
الوسطين استخدم الباحث الاختبار التائي ( t-test) لعينة واحدة فبلغت القيمة التائية المحسوبة (

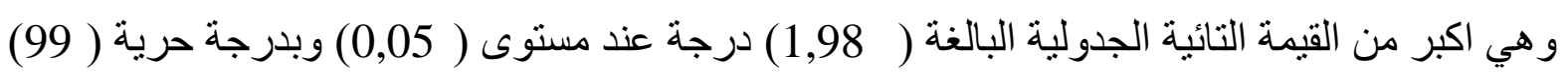
و الجدول (7) يوضح ذللك:

\begin{tabular}{|c|c|c|c|c|c|c|c|c|}
\hline مستوى & & قيمة ) & درجة & عدد & الانحراف & الوسط & الاتحراف| & الوسط \\
\hline $\begin{array}{l}\text { الدلالة } \\
(0,05)\end{array}$ & الجدولية & المحسوبة & الحرية. & العينة & المعياري & الفرضي & المعياري| & الحسابي \\
\hline
\end{tabular}

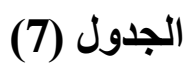

يوضح القيمة التائية لدلالة الفرق بين الوسط الحسابي والوسط الفرضي لمقياس الرضا عن العمل الارشادي لاى المرشدين التربويين. 


\begin{tabular}{|l|l|l|l|l|l|l|l|l|}
\hline دال & 1,98 & 4,905 & 99 & 100 & 1 & 120 & 29,48 & 134,46 \\
& & & & & & & & \\
\hline
\end{tabular}

ويفسر الباحث أن المرشدين التربويين لديهم رضا عالٍ جدا عن عمهم ويستمتعون بعمهر ،

و هذا يمكن ان يشير الى ان تأهيلهم الاكاديمي والمهني يتناسب مع عملهم كمرشدين تربويين ، وان وان

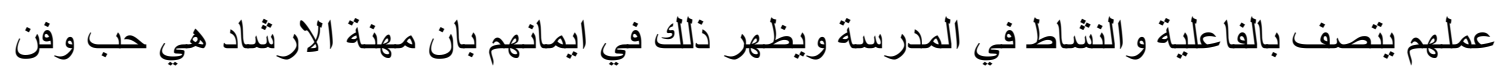

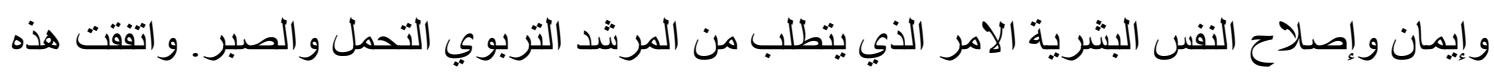

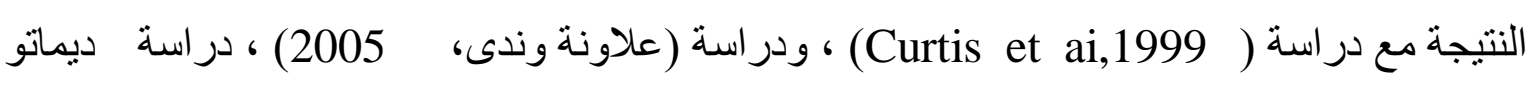
. (DeMato,2001) ومن خلال عرض النتائج وتفسيرها توصل الباحث الى الاستنتاج الآتي: كان الرضا عن العمل الارشادي لدى عينة البحث من المرشدين التربويين عالٍ و هذا ما يزيد دافعية

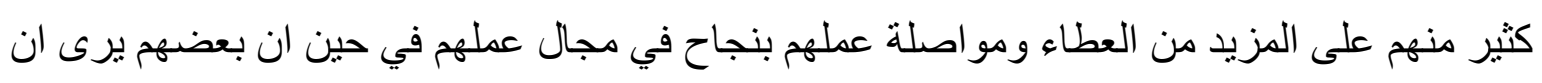

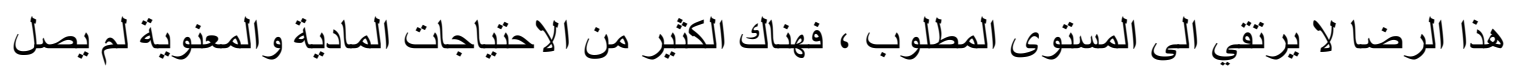

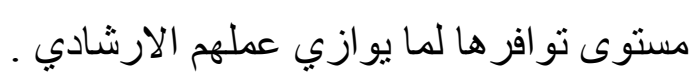

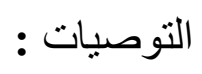

1- ضرورة الاهتمام بالمرشدين التربويين وان تحقق وزارة التربية السبل الكفيلة للعمل بالحو افز المادية

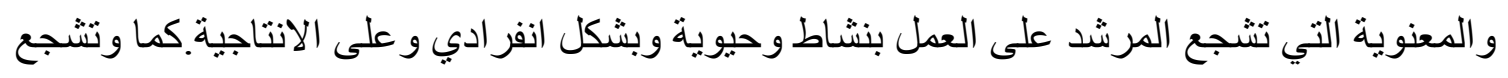
على التفكير المبدع و عمل البحوث و المشاركة بالدور التهئ. 2- تزويد المرشد التربوي بالبر امج الارشادية الموجودة بكل الاطروحات و الرسائل و البحوث للاستفادة منها في علاج المشكلات بدلا من أن يكون العلاج عشو ائيا. 
3- نوفير فرص النمو الوظيفي والترقي للمرشدين،و الاهتمام بمكانته الاجتماعية،و إبر از دوره المهني من

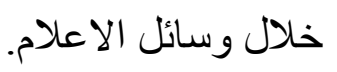

4- العمل على سد النقص في الغرف الارشادية في المدارس ، وتوفير الاثاث المكتبي وتحديد نو عه بحيث يناسب اغر اض العمل الارشادي.

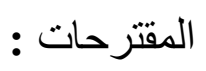

1- تطبيق الدراسة الحالية على المرشدين التربويين في محافظات اخرى و عقد مقارنات بين نتائج تلك الدراسات مع الدر اسة الحالية.

2- نوسيع الدراسة الحالية لتشمل متغير ات اخرى (الجنس، العمر، الخبرة، التخصص) . 3- الرضا عن العمل الارشادي و علاقته بالنمط القيادي الذي يمارسه المدراء.

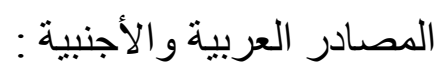

1. ابر اهيم ، نضال سمير نايف . الامن الوظيفى وعلاقته بمستوى الطموح لدى المدراء

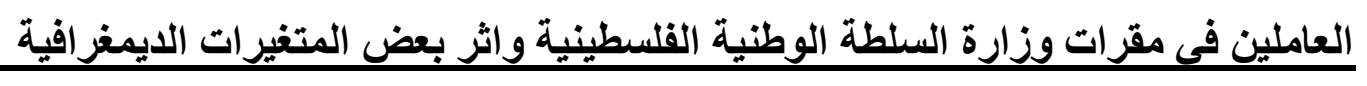
عليها ، رسالة ماجسنير غير منشور ، جامعة النجاح الوطنية، كلية الدراسات العليا، 2003. 2. بن زاهي، منصور . الثعور بالاغتراب الوظيفى وعلاقته بالدافعية للانجاز لاى الاطارات

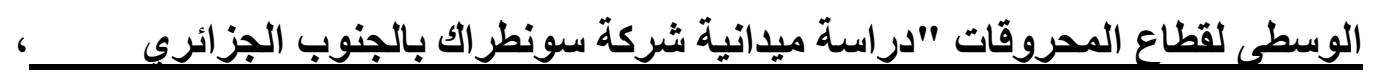
اطروحة دكتور اة غير منشورة، جامعة منتوري قسنطينة، كلية العلوم الانسانية

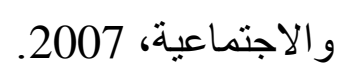

3. الجادري، عدنان حسين. الاحصاء الوصفى في العلوم التربوية، جامعة عمان العربية، كلية الدراسات التربوية العليا، عمان، دار المسيرة، عمان، الاعيان 2003.

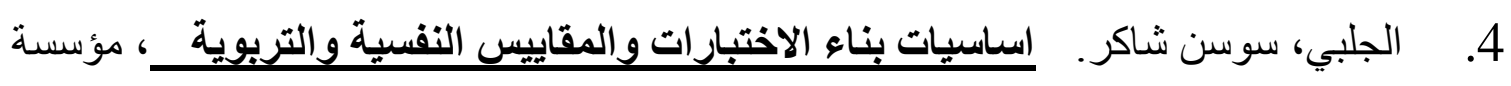

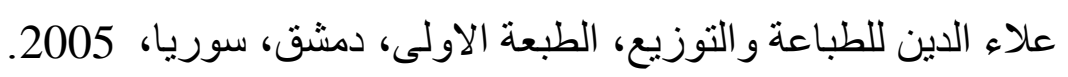


5. حريم، حسين. السلوك التنظيمى سلوك الافراد و الجماعات فى منظمة الاعمال، دار الحامد للنشر و التوزيع، الطبعة الثالثة، عمان، الاردن، 2009.

6. حمادات، محمد حسن محمد. السلوك التظيمى و التحديات المستقبلية في المؤسسات

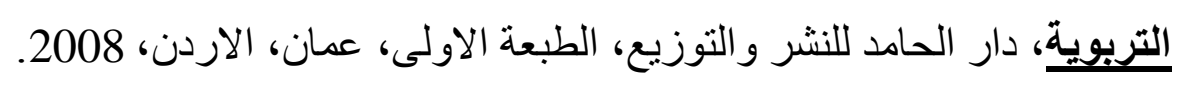

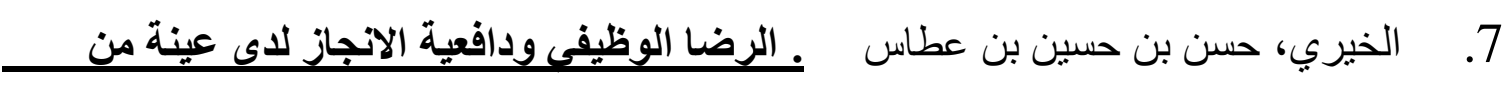

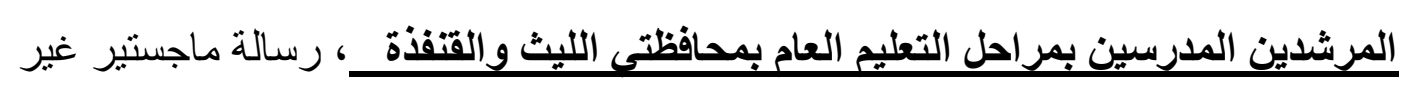
منشوره جامعة ام القرى، كلية التربية، 2008.

8. الروقي، عبد الله بن عايض. الانماط القيادية لمديري المدارس وعلاقته بالرضا الوظيفي

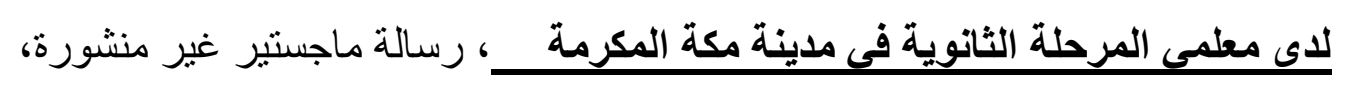
جامعة ام القرى، كلية التربية، 2012. 9. الزبيدي، رؤى رشيد كاظم. الانهاك النفسى وعلاقته بالرضا الوظيفى لاى منتسبى شرطة المرور، رسالة ماجستير غير منشورة، الجامعة المستصرية، كلية التربية، سلامة، انتصار محمد طه. مستوى الانتماء المهنى و الرضا الوظيفى والعلاقة بينهما لاى لئي .10

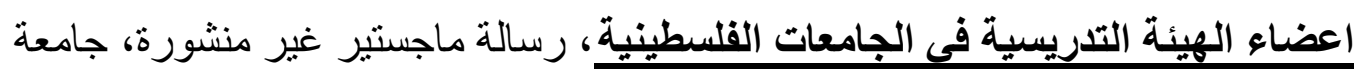
النجاح الوطنية، كلية الدراسات العليا، 2003. شرشير ، صباح سليم مصطفى. الرضا الوظيفى لاى مديري ومديرات الدو ائر فى وزارات

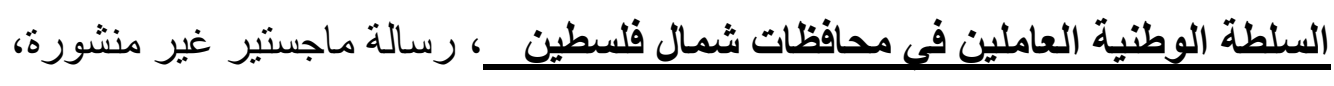
جامعة النجاح الوطنية، كلية الدراسات العليا،2000.

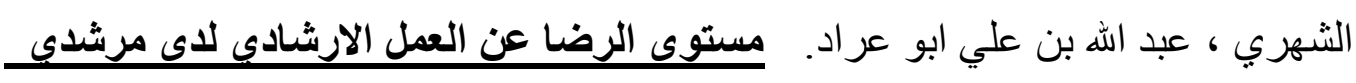
.12

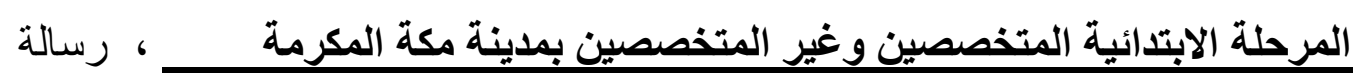
ماجستير غير منشورة ، جامعة ام القرى ، كلية التربية ، 1999.

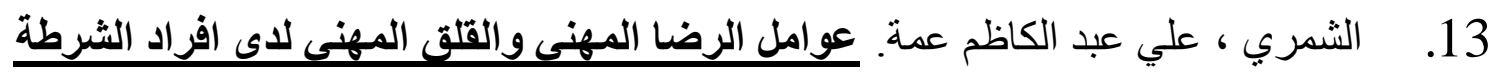

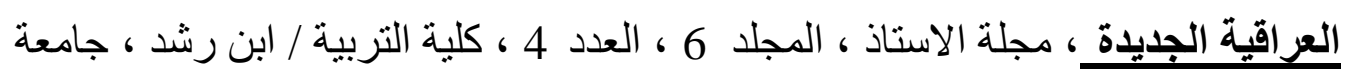
بغداد ، 2007. 
14. علاونة، معزوز جابر. يحيى محمد ندى،مستوى الرضا الوظيفى لاى المرشدين

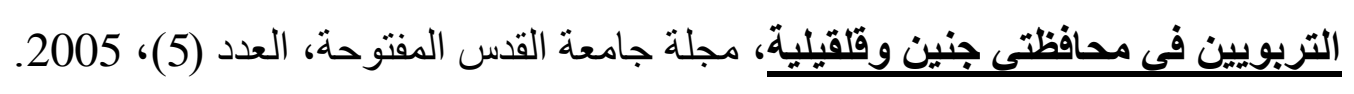

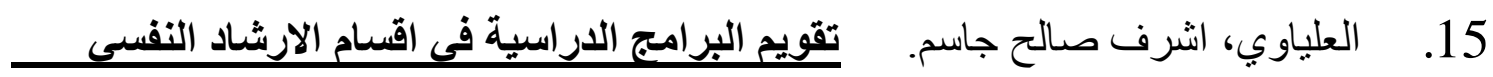

و التوجيه التربوي في الجامعات العراقية من وجهة نظر الخريجين، رسالة ماجستير غير

منشورة، جامعة البصرة، كلية التربية، 2012.

16. فلمبان، ايناس فؤاد نواوي. الرضا الوظيفى وعلاقته بالالتزام التظيمى لاى المشرفين

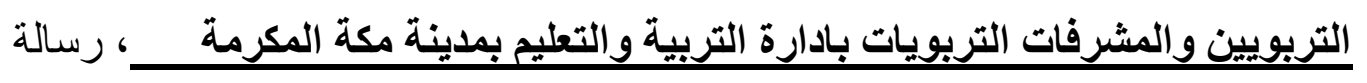

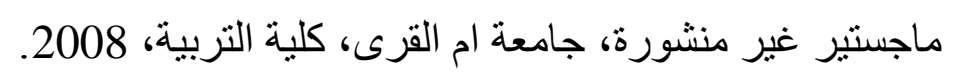

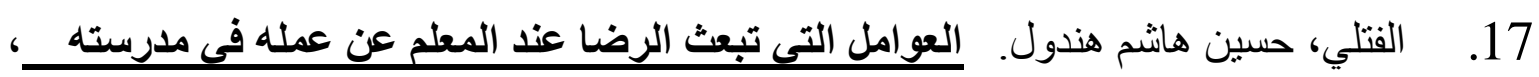

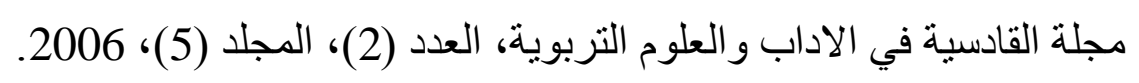
18. لباد، الزهرة. الرضا المهنى لاى المرشدين النفيين العاملين في التعليم العام وعلاقته

بعض المتغيرات، رسالة ماجستير غير منشورة، جامعة دمشق، كلية التربية، 2006.

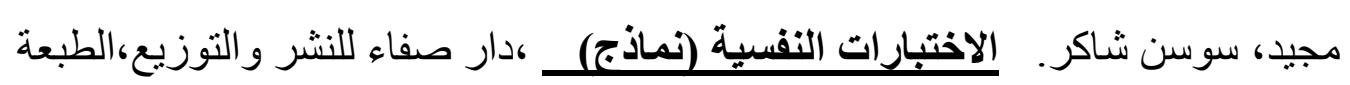

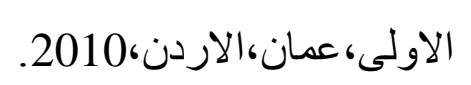

محمد، رضوان. الرضا الوظيفى وعلاقته بالابداع الاداري لاى اعضاء هيئة التدريس في كليات واقسام التربية الرياضية في اليمن، مجلة جامعة النجاح للابحاث (العلوم الانسانية)

$$
\text { العدد 5، المجلد 27، نابل } 2013 .
$$

21. نبيلة، بووذن. محددات الرضا الوظيفي لدى العامل الجزائرى في اطار نظرية دافيد

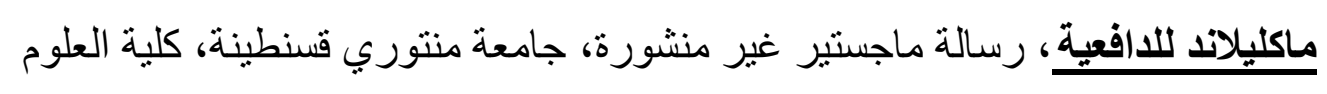

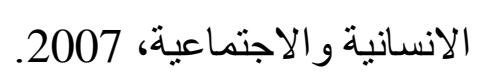

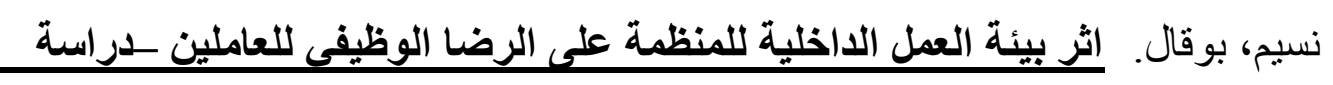

حالة_، رسالة ماجستير غير منشورة، جامعة منتوري قسنطينة، كلية العلوم الاقتصادية و علوم التسيير، وسل 2012. 
23. الويس، جنان اسماعيل طه ـ. الضغوط المهنية وعلاقتها بالرضا الوظيفى لدى مدرسى

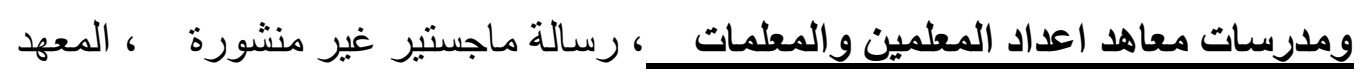

$$
\text { العربي العالي للعلوم التربوية و النفسية، } 2011 .
$$

24. يوسف ، داليا عبد الخالق عثمان. معنى الحياة وعلاقته بدافعية الانجاز الاكاديمى والرضا

$$
\text { التربية، .2008 }
$$

25. Curtis , M. J. et al (1999) Relationship among the professionats ,practices and demographic characteristics of school psychologists, School Psychology Review , 31 (1),1319. 26. Cood, carter (1973 ) .v. Dictionary Education . 3 rd .ed .New York .Mc Craw Hill .

27. Demato , Doris S. (2002) Job Satisfaction among Elementary School Counselors in Virginia , Department Counselor Education, Document Dissertation Ed-09132001 131513

28. Halpin, A. W., Theory and Research in Administration, NewYork the Macmillan Company (1966).

29. page ,Donald rothwowd (1980) The satisfiers and dissatisfiers of secondary school guidance Counselors . dissertation abstracts international .vol , 41.no College students dissertation A distracts

$$
\text { international vol .13. (11) } 3 \text {. }
$$

30.Nunnaly, H. (1978) The theory in Testing , Brooks - Hill Lon 


\section{(1) - الملحق )}

اسماء السادة الخبر اء الذين حكمو الاستبانتين

\begin{tabular}{|c|c|c|}
\hline مـكــان الــعــل & اســـــاء الخـبــراء & ت ت \\
\hline كلية التربية/ابن رشد/جامعة بغداد/قسم العلوم التربوية و النفسية. & أ.د. عبد الامير الثمسي & 1 \\
\hline كلية التربية/الجامعة المستتصرية/قسم الارشاد النفسي و التوجيه & أ.د. صالح مهدي صالح & 2 \\
\hline التربوية التربية/الجامعة المستتصرية/قسم الارشاد النفسي و التوجيه & أ.د. نادية شعبان مصطفى & 3 \\
\hline التربوية التربية/الجامعة المستتصرية/قسم الارشاد النفسي و التوجيه & أ.م.د. يجيى داود الجنابي & 4 \\
\hline و التية التربية للعلوم الانسانية/جامعة البصرة/قسم الارشاد النفسي & أ.م.د. بــتول بناي زبــــــري & 5 \\
\hline و التية التربية للعلوم الانسانية/جامعة البصرة/قسم الارشاد النفسي & أ.م.د. عياد اسماعيل السامر ائي & 6 \\
\hline و التية التربية للعلوم الانسانية/جامعة البصرة/قسم الارشاد النفسي & أ.م.د. هناء عبد النبي العبادي & 7 \\
\hline و النفية التربية للعلوم الانسانية/جامعة ذي قار/قسم العلوم التربوية & أ.م.د. انعام قاسم الصريفي & 8 \\
\hline كلية التربية للعلوم الانسانية/جامعة البصرة/قسم الارشاد النفسي & أ.م.د. صفاء عبد الزهرة الجمعان & 9 \\
\hline
\end{tabular}




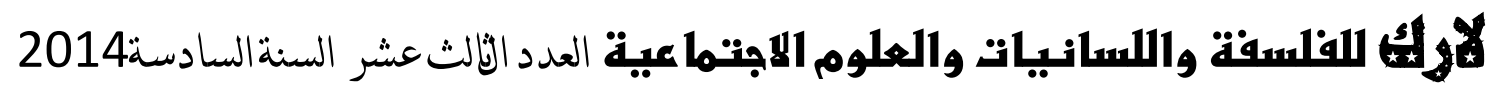

\begin{tabular}{|c|c|c|}
\hline و التوجيه التربوي. & & \\
\hline كلية التربية/ابن رشد/جامعة بغداد/قسم العلوم التربوية و النفسية. & أ.م.د. خـالا جمال قـاسم & 10 \\
\hline كلية التربية للعلوم الانسانية/جامعة البصرة/قسم اللغة العربية & م.د.علي جاسب عبد الله & 11 \\
\hline
\end{tabular}

$$
\text { بســم الله الرحمن الرحيــم }
$$

(2) (2) (2) (2) (2)

مقياس الرضا عن العمل الارشادي بصيغته النهائية

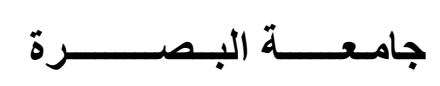

كلية التربية للعلوم الانسانية

قسم الارشاد النفسي والتوجيه التربوي/الاراسات العليا

$$
\begin{aligned}
& \text { زميـــلتي المرشــــة التربوية }
\end{aligned}
$$

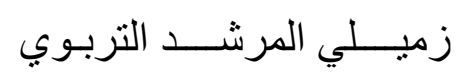

تحية طيبة... 
بين يديك الان مقياس(الرضا عن العمل الارشادي) متعلق بعمل المرشد التربوي الغرض منه تشخيص جانب مهم من جو انب العملية التربوية وان نتائجه سوف تكون ذات فائدة في مسيرة التربية والتعليم ودعما لجهودك لك المبذولة في هذا الجانب.

لذا يرجو الباحث تعاونلك معه، و أساس هذا التعاون هو ان تكون صريحا في اجابتك على فقرات المقياس . علما ان المعلومات التي تعطيها سوف تستعمل لإغر اض البحث العلمي فقط وسوف لن بطلع عليها احد سوى الباحث لذلك لا داعي لذكر الاسم وان ما يقوم به الباحث هو جزء من متطلبات درجة الماجستير. في الصفحات الاتية ترى امامك عدداً من الفقرات و إز اءها مقياس من خمسة بدائل لذا يرجى التفضل بقر اءة كل فقرة بدقة ثم اختيار نوع البديل وذلك بوضع علامة ( ) في الحقل الذي ينطبق عليك..وقبل قر اعة فقرات المقياس.

يرجى الاجابة على الاسئلة التالية:

عدد سنوات الخدمة:

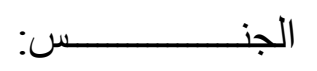

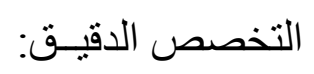
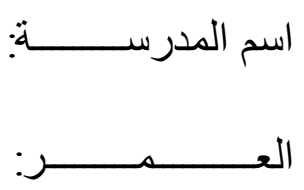

الحالة الاجتماعية:

$$
\text { طلي رسن شندوخ }
$$




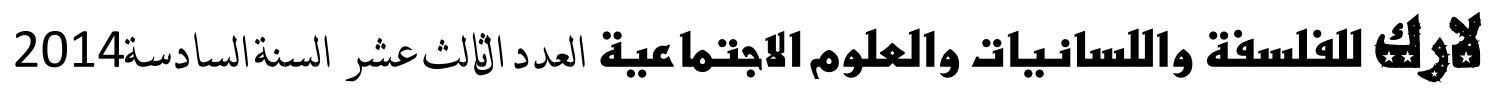

وتقبلو افائق الثكر والأمتنان...

\begin{tabular}{|c|c|c|c|c|c|c|}
\hline & & & & & \multicolumn{2}{|c|}{ المجال الاول/الرضا عن العمل مع ادارة المدرسة. } \\
\hline غير راض & غراض & راض الى ما & راض & راض & الفقراتٍ & ت \\
\hline & & & & & داخل احترام الاراء والأفكار التي تطرحها & 1 \\
\hline & & & & & 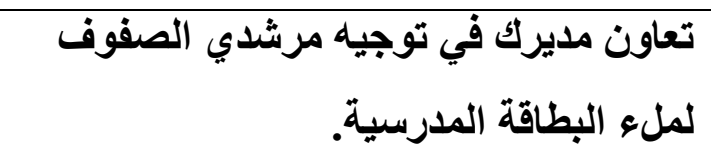 & 2 \\
\hline & & & & & مدى تفهم وتقدير ادارة المدرسة لمهامك & 3 \\
\hline & & & & & نوع المكان المخصص للك(غرفة ، قاعة، & 4 \\
\hline & & & & & رالعمل. الفعل الذي تلمسه لدى مديرك عند اجادتك & 5 \\
\hline & & & & & ل الثاني/الرضا عن العمل مع الهيئة التّريسية.ة. & \\
\hline 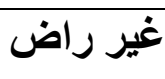 & غير & 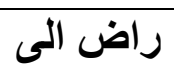 & 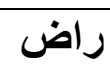 & & الفقرات & 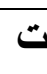 \\
\hline
\end{tabular}




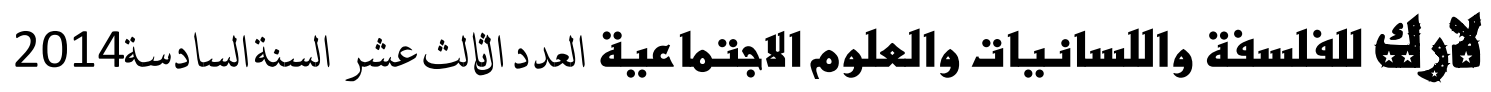

\begin{tabular}{|c|c|c|c|c|c|c|}
\hline |طلاقا & راض & 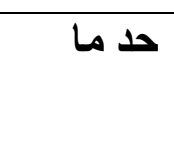 & & جداض & & \\
\hline & & & & & طبيعة العلاقة بينك وبين اعضاء الهيئة & 6 \\
\hline & & & & & توجيهاتك وتثاون الهيئة التدريسية معك في تنفيذ الطلبة على مراجعتك. & 7 \\
\hline & & & & & تلدخل بعض المدرسين في عملك في حل & 8 \\
\hline & & & & & تلتدقيق زملائك في المدرسة للجهـ الذي تبذله & 9 \\
\hline & & & & & الثالث/الرضا عن العمل مع الطلبة. & 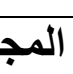 \\
\hline غير راض & غراض & راض الى ما & 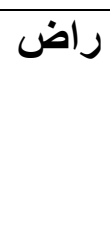 & راض & الفقرات & ت \\
\hline & & & & & طبيعة العلاقة المهنية بينك وبين الطلبة. & 10 \\
\hline & & & & & مستوى تقبل الطلبة المسترشدين للمساعدة & 11 \\
\hline
\end{tabular}




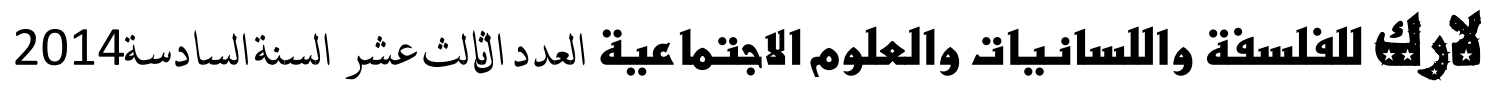

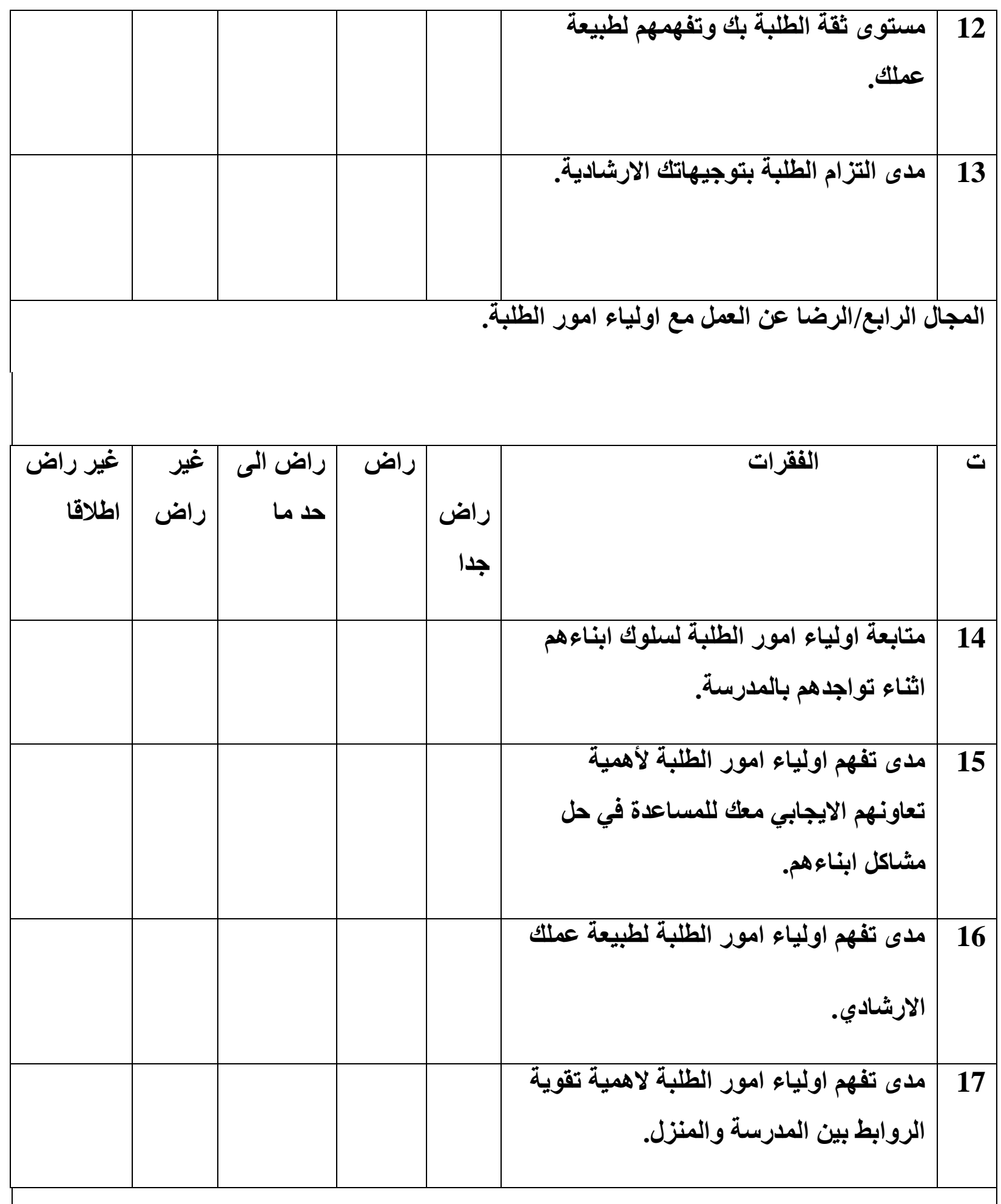




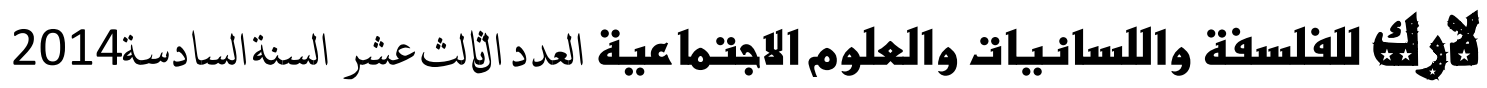

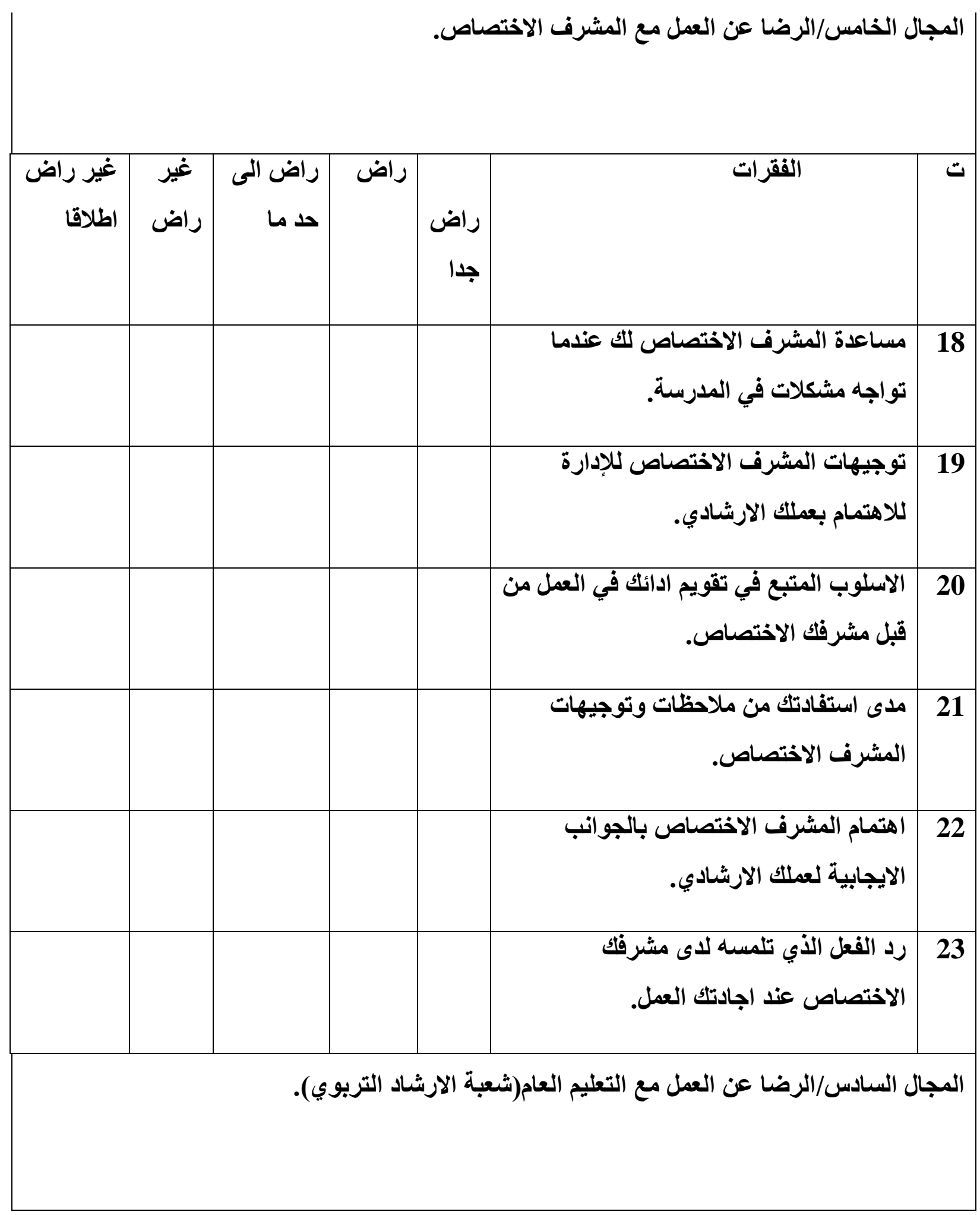




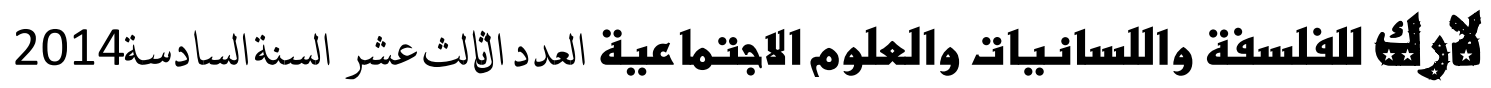

\begin{tabular}{|c|c|c|c|c|c|c|}
\hline غ غلاض راض & راض & حـ ماض الى & راض & راض & الفقرات & $ت$ \\
\hline & & & & & ترسلها. & 24 \\
\hline & & & & & مدى حصولك على المصادر والكتب الحديثة & 25 \\
\hline & & & & & 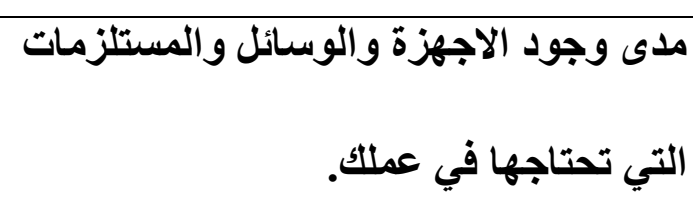 & 26 \\
\hline & & & & & 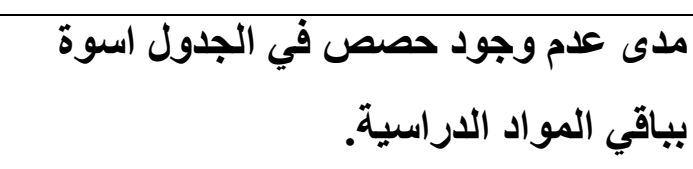 & 27 \\
\hline
\end{tabular}

المجال السابع/الرضا عن العمل نفسه وظروفه المادية.

\begin{tabular}{|c|c|c|c|c|c|c|}
\hline غ غلاض راض & غراض & حد ماض الى & راض & جاض & الفقرات & ت \\
\hline & & & & & مصور تناسب الوقت مع العمل الذي تقدمه & 28 \\
\hline & & & & & مقلده من قبلك. & 29 \\
\hline
\end{tabular}




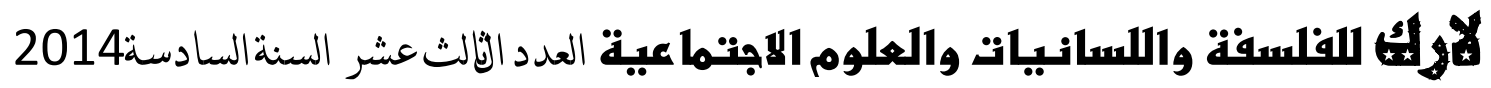

\begin{tabular}{|c|c|c|c|c|c|c|}
\hline & & & & & الثخصية. حجم العمل ومدى ملائمته لقدراتك وخبراتك & 30 \\
\hline & & & & & ما يتيحه للك عملك فرص المشاركة في اتخاذ & 31 \\
\hline & & & & & ظروف العمل وبيئته & 32 \\
\hline & & & & 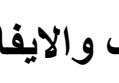 & ل الثامن/الرضا عن الندوات والدورات والتدريد & المجا \\
\hline غ غيلاض راض & راض & راض الى ما & 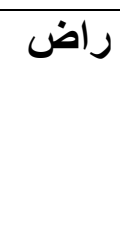 & راض & الفقرات & ت \\
\hline & & & & & 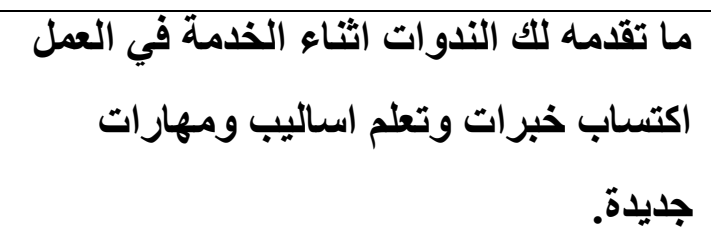 & 33 \\
\hline & & & & & كفاعة اعدادك للعمل الارشادي. & 34 \\
\hline & & & & & 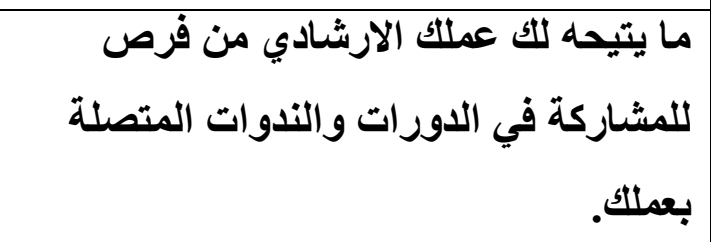 & 35 \\
\hline
\end{tabular}




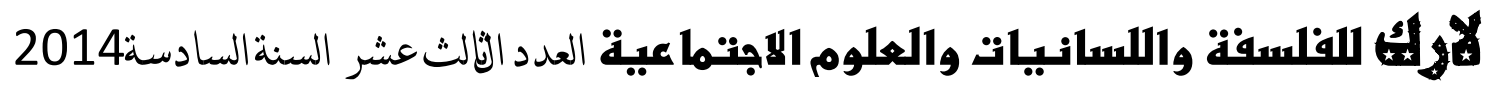

\begin{tabular}{|c|c|c|c|c|c|c|}
\hline & & & & & 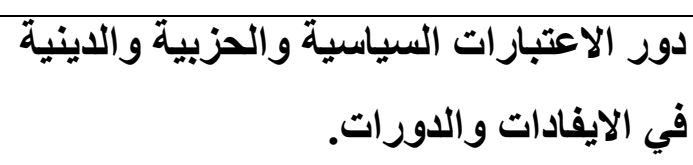 & 36 \\
\hline \multicolumn{7}{|c|}{ المجال التاسع/الرضا عن الراتب والحوافز والترقيات. } \\
\hline غ غيلاض راض & راض & راض مالى ما & 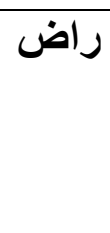 & راض & الفقرات & 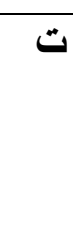 \\
\hline & & & & & ملدي تناسب راتبك الذي تثتاضاه مع العمل & 37 \\
\hline & & & & & مناسبة راتبك لمتطلبات الحياة الاساسية. & 38 \\
\hline & & & & & 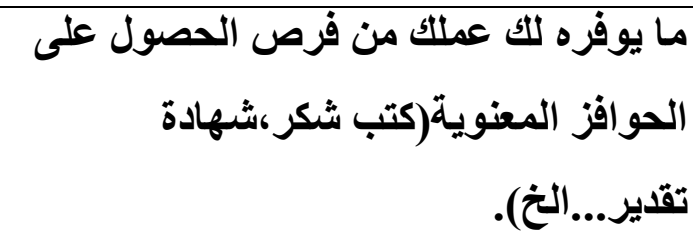 & 39 \\
\hline & & & & & ما ما يوفره للك عملك الارشادي فرص التقدم & 40 \\
\hline
\end{tabular}

